\title{
Determinants of Growth Spells: is Africa Different?
}

Charalambos G. Tsangarides 


\title{
IMF Working Paper
}

Research Department

\section{Determinants of Growth Spells: is Africa Different?}

\section{Prepared by Charalambos G. Tsangarides*}

Authorized for distribution by Atish R. Ghosh

September 2012

\section{This Working Paper should not be reported as representing the views of the IMF.}

The views expressed in this Working Paper are those of the author(s) and do not necessarily represent those of the IMF or IMF policy. Working Papers describe research in progress by the author(s) and are published to elicit comments and to further debate.

\begin{abstract}
Do growth spells in Africa end because of bad realizations of the same factors that influence growth spells in the rest of the world, or because of different factors altogether? To answer this question, we examine determinants of growth spells in Africa and the rest of the world using Bayesian Model Averaging techniques for proportional hazards models. We define growth spells as periods of sustained growth episodes between growth accelerations and decelerations and then relate the probability that a growth spell ends to various determinants including exogenous shocks, physical and human capital, macroeconomic policy, and sociopolitical factors. Our analysis suggests that determinants of growth spells in Africa are different from those in the rest of the world. The majority of the identified robust determinants have a distinct impact in only one of the two samples: initial income, terms of trade, exchange rate undervaluation and inflation, influence spells only in the world sample, while openness and droughts seem to only affect Africa. In addition, a few common determinants - proxies for human and physical capital and changes in the world interest rate-have very different marginal effects in the two samples.
\end{abstract}

JEL Classification Numbers: O11, O40, C11

Keywords: International Growth, survival analysis, robustness, Bayesian Model Averaging Author's E-Mail Address: ctsangarides@imf.org

\footnotetext{
* I am grateful to Andy Berg, Daniel Brou, Rex Ghosh, Eduardo Ley, Alin Mirestean, Chris Papageorgiou, Mahvash Qureshi, Nicola Spatafora, colleagues at the Research and African departments of the IMF, and seminar participants at the 2012 Canadian Economics Association Meetings (Calgary) and 2012 CSAE Conference (Oxford) for helpful comments and suggestions, and Edith Laget for excellent research assistance. The usual disclaimer applies.
} 


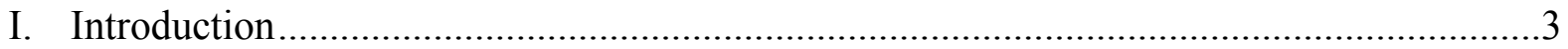

II. Identifying Growth Spells and Their Determinants ...................................................5

A. From Structural Breaks to Growth Spells .................................................................5

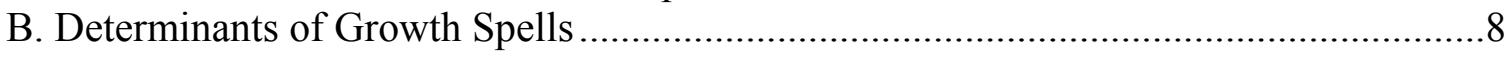

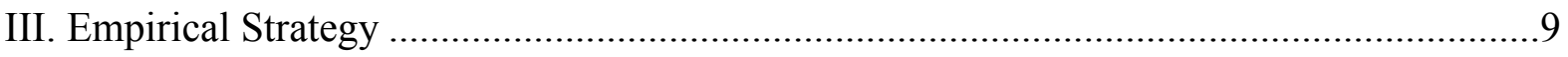

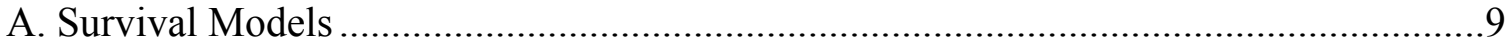

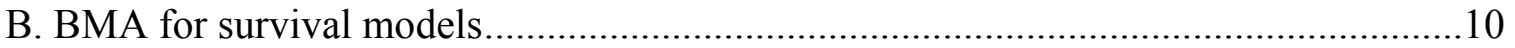

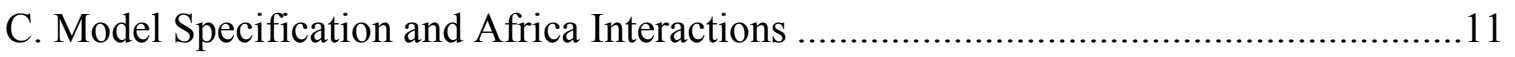

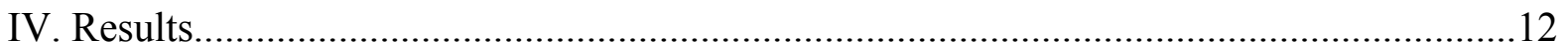

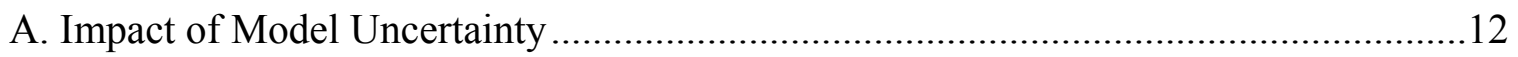

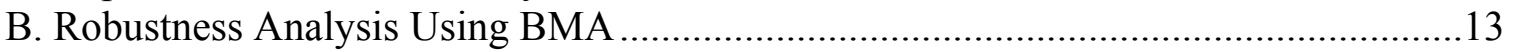

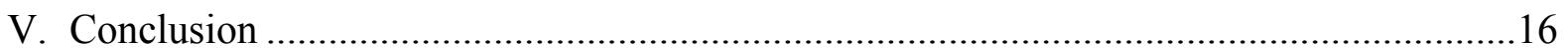

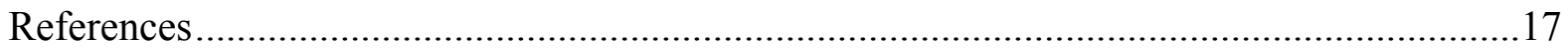

Tables

1. Growth Breaks by Country Group .......................................................................21

2. Stylized Facts about Growth Spells ...........................................................................22

3. Evidence for Lack of Robustness from Ad Hoc Growth Regressions.............................23

4. Posterior Coefficient Estimates for Growth Spells for Africa, Non-Africa, and World....24

Figures

1a. Upbreaks and Downbreaks: Hills, Cliffs, Mountains, and Plateaus ...............................25

1b. Upbreaks and Downbreaks: Hills, Cliffs, Mountains, and Plateaus in Africa..................26

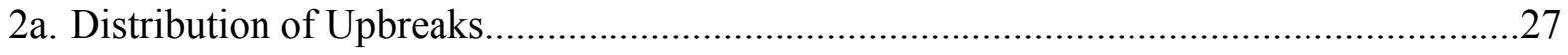

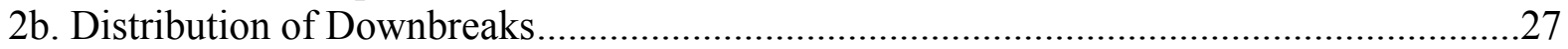

3. Duration of Growth Spells and Explanatory Variables ................................................28

Appendix........................................................................ 31 


\section{INTRODUCTION}

Following an extensive literature on average growth performance, a new strand of the literature has recently begun to investigate the frequency and duration of growth episodes. This is motivated by two views. First, differences in average growth rates across countries stem not so much from constant differences in growth as from variations in the volatility of growth - industrial and some emerging markets grow fairly consistently, while most developing countries alternate between episodes of very fast growth and episodes of stagnation or decline. Second, if the frequency of growth accelerations is fairly constant across regions, then it is the duration of these episodes that accounts for the very different growth rates across countries or regions (Pritchett, 2000; and Jones and Olken, 2008).

Pritchett (2000) characterizes countries' growth patterns as one of five types: periods of steady and rapid growth ("hills"), steady and rapid growth followed by declines ("mountains"), steady declines ("valleys"), catastrophic falls ("cliffs"), or stagnations ("plateaus") as in Figures 1a and 1b. Ensuing research attempts to explain these patterns of growth. ${ }^{1}$ Techniques for identifying growth episodes and for testing correlates vary across papers and cover a broad range of potential determinants. These include the macroeconomic environment, trade, investment, institutions, and geographical aspects - some of which are thought to trigger and others to enable an acceleration to continue and become a growth spell. Broadly, conclusions suggest that identified determinants are idiosyncratic, unrelated to "standard" growth determinants, and that they explain little of the variation in the frequency or duration of growth spells.

A recent paper by Berg, Ostry, and Zettelmeyer (BOZ, 2012) is an important departure from earlier literature. Rather than looking at growth before-and-after deceleration periods, they focus on growth duration and examine what determines of the length of "growth spells" defined as periods of high growth following a growth up-break and ending either with a growth down-break or with the end of the sample. This approach is motivated by the fact that while surges in growth are common in the developing world - even in regions such as subSaharan Africa - what is interesting to examine is why some of these surges become spells, and why some last longer than others. After an extensive analysis, BOZ find that the duration of growth spells is positively related to the degree of equality of the income distribution, democratic institutions, export orientation, and macroeconomic stability.

Despite the vast literature on the empirics of growth more broadly, there is little consensus on what the determinants of growth are. A fundamental problem confronting growth researchers is the lack of an explicit theory identifying growth determinants which allows a wide range

\footnotetext{
${ }^{1}$ See for example, Hausman, Pritchett, and Rodrik (2005), Hausman, Rodrigues, and Wagner (2006), Jermanowski (2006), Aizenman and Spiegel (2007), Jones and Olken (2008), and Pattilo, Gupta, and Carey (2005).
} 
of possible and testable specifications. As a result, researchers started investigating the robustness of possible empirical relations by formally incorporating model uncertainty in the analysis using Bayesian Model Averaging (BMA) methods. ${ }^{2}$ These methods provide a solid theoretical foundation for addressing model uncertainty in the empirical growth analysis by assuming that the researcher does not know which model specification is the "true" one and thus needs to attach probabilities to different possible models. Inferences are then based on a weighted average of the full model space instead of on one selected model, thus incorporating uncertainty in both predictions and parameter estimates.

Researchers have long been interested in the mechanics of growth in Africa. Work on Africa's average growth performance often labels Africa's growth experience after decolonization an "economic tragedy," generating an almost universally pessimistic consensus about the continent's economic prospects. Some of the earlier empirical work on how Africa's growth compares to that in the rest of the world is based on the inclusion of an African regional dummy in the global sample specification; a significant African regional dummy was often interpreted as evidence that these growth models cannot fully account for Africa's different growth performance. Overall, conclusions are mixed. While several studies (e.g. Temple, 1999; Collier and Gunning, 1999; and Block, 2001) find that marginal impacts and the transmission mechanisms may be different in Africa compared to the rest of the world, others find that the growth process in Africa is not different from that in the rest of the world (Easterly and Levine, 1997; Sachs and Warner, 1995; and Rodrik, 1998). Using BMA techniques to incorporate considerations about model or parameter uncertainty, Brock and Durlauf (2001), Artadi and Sala-i-Martin (2003), and Masanjala and Papageorgiou (2008) conclude that the determinants of growth in Africa are different from those in the rest of the world, while, in contrast, Tsangarides (2005) finds a set of common robust determinants that are universally important for growth in both the world and in Africa.

This paper brings all these strands of the literature together. We investigate the robustness of growth spell determinants in the world and Africa using BMA techniques for proportional hazards models of censored survival data. In this framework, we estimate and compare proportional hazard models for two samples - Africa and the rest of the world - relating the probability that growth spells will end to the various determinants including exogenous shocks, human capital, macroeconomic and sociopolitical and factors. Our contribution to the existing literature is thus two-fold. First, we systematically examine determinants of growth spells duration while accounting for model uncertainty using BMA. Since there is no explicit theory about what determines growth spells, BMA is particularly applicable to investigate correlates of growth spells. To the best of our knowledge, this is the first attempt of its kind. Second, unlike previous studies which focus on growth spells for the world as a

\footnotetext{
${ }^{2}$ Fernández, Ley, and Steel (2001), Brock and Durlauf (2001), and Sala-i-Martin, Doppelhofer, and Miller (2004) formally introduced model averaging to the growth empirics literature.
} 
whole ignoring heterogeneity, we investigate whether determinants of growth spells operate differently in Africa than in the rest of the world.

Our analysis finds several robust determinants of growth spells including proxies for initial conditions, physical and human capital, exogenous factors, and the macroeconomic environment. These determinants, however, operate differently in Africa suggesting that the empirics of growth spells in Africa are different compared to the rest of the world. In particular, out of nine identified robust variables, six variables - initial income, terms of trade, exchange rate undervaluation, openness and droughts - have a distinct impact in only one of the two samples. In the non-Africa sample, spell duration is positively related to both physical and human capital and terms of trade growth, while exchange rate overvaluation, inflation, changes in the U.S. interest rate and initial income are unfavorable for spell duration. Increased openness and droughts have a distinct impact in the Africa sample only, and are negatively related to growth spell duration. In both Africa and the rest of the world, physical and human capital, and changes in the U.S. interest rate are robustly correlated with growth spells, but estimated marginal effects and hazard ratios vary substantially between the two samples.

The rest of the paper is organized as follows. Section II defines the growth spells, presents stylized facts, and proposes the potential determinants used in our analysis. Section III discusses the empirical strategy. Section IV presents the results. Section V concludes.

\section{IDENTIFying Growth SPELlS AND Their DeterminantS}

\section{A. From Structural Breaks to Growth Spells}

\section{Structural breaks}

Antoshin et al. (2008) develop a variant of the Bai and Perron (1998) procedure to test for multiple structural breaks in time series when both the total number and the location of breaks are unknown. ${ }^{3}$ Using this method, we follow BOZ to identify structural breaks in economic growth in 140 countries. For the period of analysis $T$, the procedure requires defining the minimum years between breaks $h$, which effectively determines the maximum

\footnotetext{
${ }^{3}$ Extending Bai and Perron's (1998) procedure, Antoshin et al. (2008) allow sequential testing of the breaks and uses sample specific critical values to take into account the small sample and heteroskedasticity. They show that for most types of data generating processes in samples with as low as 50 observations, their proposed modifications perform substantially better than that of Bai and Perron (1998).
} 
number of breaks $b$ for each country where $b=\operatorname{int}\left(\frac{T}{h}\right)-1 .^{4}$ Allowing 5 minimum years between breaks $(h=5)$ results in a maximum of 9 possible breaks for a country with $T=50$; averaging of 5 years is also typically used in panel growth regressions as a unit of averaging. On the other hand, a larger number of minimum years between breaks such as $h=8$ also seems reasonable in order to eliminate short-term fluctuations or cyclical factors. Further, in order to assign a statistical significance of the identified breaks, we follow BOZ and define the allowable significance value $p$, and experiment with critical values $p=0.10$ and $0.25 .^{5}$

Table 1 shows the distribution of the identified breaks for per capita growth rates from version 6.2 of the Penn World Tables. We group "upbreaks" and "downbreaks" by region, for critical values of 0.10 and 0.25 , and for breaks not closer than 5 or 8 years. We begin with some descriptive statistics. With 5 years between breaks and $p=0.10,137$ upbreaks and 150 downbreaks are identified. As expected, higher values of $p$ and lower values of $h$ result in more identified breaks. In particular, about one and a half times more upbreaks and downbreaks are identified with the higher $p$ value of 0.25 , while restricting the minimum length of spell to 8 years increases the total number of breaks by about 40 percent compared to the 5 year minimum spell limit for $p=0.10$ and $p=0.25 .^{6}$

Despite these differences, none of these choices substantially affect the distributions of upbreaks and downbreaks. For example, irrespective of the method defining the breaks, about one-third of either upbreaks or downbreaks occur in Africa and break sizes are comparable across methods. As a result, we focus our analysis on the $h=5$ and $p=0.10$ case which maximizes the number of accurately measured breaks for a reasonable minimum number of years between breaks. Figures $2 \mathrm{a}$ and $2 \mathrm{~b}$ show the distribution of upbreaks and downbreaks by country group and across decades. Upbreaks on average across groups tend to be most common in the 1950s, 60s, and 90s. For the 1950s, and 60s breaks are evenly distributed across county groups, while Africa accounts for almost one-half of upbreaks in the 1990s. Downbreaks are more frequent in the 1970s and mostly occur in industrialized countries and Africa. Latin America had most of its upbreaks and downbreaks in the 1980s.

\footnotetext{
${ }^{4}$ Allowing larger values of $h$ could miss breaks that are closer than $h$ periods apart, while at the same time, small values of $h$ would force the structural break test to be undertaken on data subsamples containing as few as $2 h+$ lobservations. For more details, refer to BOZ.

${ }^{5}$ These critical values are specific to the time series in question (and their associated means and variances) and are not based on asymptotic critical values, so their interpretation is different.

${ }^{6}$ In general, allowing for a shorter frequency for spells may pick up abrupt output movements reflecting volatility or business cycles, but, at the same time, larger frequencies may miss smaller or shorter-lived spells. Also, while higher critical values increases the total number of breaks identified, they come at the expense of more "false positives" (that is, identifying a break when there is none).
} 


\section{Growth spells}

Using the identified upbreaks and downbreaks we follow BOZ to define "complete" growth spells as periods of time that (i) begin with a growth upbreak followed by a period of at least 2 percent average per capita income growth; and (ii) end with a growth downbreak followed by a period of less than 2 percent average per capita income growth. Similarly, "incomplete" growth spells can be defined as those that satisfy condition (i) and are still on-going at the end of the sample. ${ }^{7}$

Table 2 examines the frequency and duration of growth spells and some stylized facts. About a third of the spells identified at each level correspond to Africa, which is roughly the share of African countries in the sample. However, while it is not unusual for African countries to get growth going, the issue is the ability to sustain these spells over long periods. As also noted by BOZ, irrespective of the minimum length of spell and critical value definitions, the mean length of growth spells in Africa is always much shorter compared to the average and other regions: complete spells in Africa last about 6 years on average compared to 13 and 21 years for industrialized and Emerging Asia countries, respectively. Spells in Emerging Asia are not just more likely to last longer; it is also the case that most spells in Emerging Asia also last longer: seven out of ten of the spells in Emerging Asia last at least 16 years, compared to only one in ten spells in industrialized and Latin American countries lasting at least 16 years.

Countries' growth experience before, during, and after the end of spells varies substantially. Spells in Emerging Asia and high income countries tend to start from much higher per capita growth rates than those in developing countries. Also, in Africa and Latin America spells tend to begin from high negative growth rates on average. Overall, growth rates during spells are relatively similar across regions. In Africa, growth during spells is a bit higher than the average, while in Latin America, the opposite is true. Perhaps the most important differences are in the growth rates after the growth spells end. On average, growth after the end of a complete spell is about -1 percent in high income and Emerging Asian countries suggesting a "soft landing" when the spell ends. In contrast, in Africa, growth after the end of a spell averages -3.2 percent, and -3.7 percent three years after the end of the spell. ${ }^{8}$ In summary,

\footnotetext{
${ }^{7}$ It is possible to define periods of sustained negative growth rates and investigate their determinants. Jones and Olken (2005) stress the asymmetry between accelerations and collapses of growth: what works to get growth going is not the opposite of what seems correlated with a downbreak. This would suggest that the correlates of upbreaks differ from those of downbreaks. We are currently exploring these ideas in a separate project.

${ }^{8}$ The finding that Africa's spells are shorter and that they end badly does not depend on the comparator group or the classification used. In particular, grouping Latin America, Caribbean and Middle Eastern countries together, average spell duration is 9.2 years and growth after the end of a spell is -1.2 percent. Including Africa in the group, namely grouping Latin America, Caribbean, Middle Eastern and African countries together, results in an average spell duration of 8.1 years and growth after the end of a spell is -1.8 percent. Finally, using a definition for advanced, emerging, and developing countries excluding Africa, the average spell duration, in years (and growth after the end of a spell, in percent) are $12.6(-0.6), 15.3(-1.5)$, and $7.3(-0.8)$, respectively.
} 
Africa's spells are different: they are shorter than elsewhere in the world, and they end up in "rough landings."

\section{B. Determinants of Growth Spells}

The stylized facts discussed above suggest that Africa's growth spells are different than those in the rest of the world. We now investigate how potential correlates of spell duration influence the probability that a spell will continue or come to an end, and how these may be different in Africa.

Due to the lack of clear theoretical guidance (and tradeoffs) on what influences growth spell duration - the classic case of model uncertainty - we follow a two-part approach. First, we resort to BMA techniques, which provide a coherent mechanism to address the problem of model uncertainty. ${ }^{9}$ The application of BMA techniques in the broader empirical growth literature has been standard practice in the literature as a method to formally incorporate model uncertainty. ${ }^{10}$ Second, we draw the pool of our potential determinants from the few papers in the relevant literature on growth spells and accelerations, combined with findings from the broader literature on growth empirics. At the same time, we ensure a sample size that allows enough degrees of freedom for estimation.

As a result, we consider growth determinants that capture proposed growth theories, policies, institutional characteristics, and other exogenous factors that stimulate growth. In addition to the variables suggested by the "augmented" neoclassical Solow model, surveys of the empirical growth literature (e.g. Durlauf, Johnson and Temple, 2005) identify a large number of explanatory variables grouped into "categories" or distinct growth theories. ${ }^{11}$ In addition, variables that have been used to explain Africa's poor economic performance include those arising from policy, politics and institutions, and exogenous factors beyond the influence of the domestic domain. Policies usually believed to hinder growth in Africa include poor (macroeconomic) fiscal, exchange rate, and trade policies, high inflation, and poorly functioning financial markets (Fischer, 1993; and Frankel and Romer, 1999). Negative political effects arise from lack of good institutions, democracy, and good governance (Knack and Keefer, 1995; Collier and Gunning, 1999; and Acemoglu, Johnson, and Robinson, 2001). Finally, exogenous factors cited include external aid (Burnside and Dollar (1997)), and ethnolinguistic fractionalization (Easterly and Levine (1997)).

\footnotetext{
${ }^{9}$ Model uncertainty was initially pointed out by Leamer (1978) and later elaborated by Brock and Durlauf (2001). Seminal contributions to BMA include those of Raftery (1995), and Raftery, Madigan and Hoeting (1997).

${ }^{10}$ Fernández, Ley and Steel (2001), Brock and Durlauf (2001), Brock, Durlauf and West (2003), Sala-i-Martin, Doppelhofer, and Miller (2004), Tsangarides (2005), Masanjala and Papageorgiou (2008), and Mirestean and Tsangarides (2009) have used BMA techniques to investigate cross-country growth determinants.

${ }^{11}$ In an attempt to test growth theories rather than particular variables, Durlauf, Kourtellos, and Tan (2008) assign priors to various combinations of empirical proxies for a given theory.
} 
Based on the above discussion, we consider four broad categories of potential determinants of growth spells: (i) the neoclassical/Solow determinants and human capital (proxied by initial income per capita, population growth, investment to GDP, and total education years); (ii) external shocks and exogenous factors proxied by terms of trade growth, change in the US interest rate, change in oil price, drought, and shock to terms of trade; (iii) macroeconomic policy (proxied by capital flows to GDP, external debt liabilities to GDP, openness, exchange rate undervaluation, inflation, government balance to GDP, and aid to GDP; and (iv) institutions and heterogeneity (proxied by changes in autocracy and ethnic heterogeneity). The Appendix discusses definitions and sources of the variables.

We investigate how these variables relate to the duration of growth spells in Figure 3 for the full sample of countries. Each of the potential determinants of growth spells is plotted against the duration (length) of the growth spell. In a way, these plots are analogous to two-way scatter plots of the dependent variable against each of the regressors. Some preliminary patterns emerge suggesting that, ceteris paribus, higher per capita income, higher population growth, increases in US interest rate, increases in oil prices, terms of trade shocks, more exchange rate overvaluation, higher inflation, higher aid, and higher ethnic heterogeneity are associated with shorter spell duration. On the other hand, higher investment, higher education, and openness seem to increase spell duration.

\section{EMPIRICAL STRATEGY}

\section{A. Survival Models}

Survival analysis models the time it takes for events to occur-in our case, the end of the growth spell. Typically, the relationship of the survival distribution is related to covariates that may influence the probability that a growth spell ends. Let $T$ denote survival time (duration), a random variable with a cumulative distribution function $F(t)=\operatorname{Pr}(T \leq t)$. The survival function $S(t)$ is the complement of the distribution function $S(t)=\operatorname{Pr}(T>t)=1-F(t)$. Methods for analyzing survival data often focus on modeling the hazard rate, which is another representation of the distribution of survival times, which assesses the instantaneous risk of demise at time $t$, conditional on survival up to that time

$$
h(t)=\lim _{\Delta t \rightarrow 0} \frac{\operatorname{Pr}[(t \leq T \leq t+\Delta t) \mid T \geq t]}{\Delta t}=\frac{f(t)}{S(t)} .
$$

The most popular way of modeling the hazard rate is to use the Cox (1972) proportional hazards method, which allows different hazard rates for cases with different covariate vectors and leaves the underlying common baseline hazard rate unspecified. The Cox model specifies the hazard rate for subject $i$ with covariate vector $X_{i}$ as

$$
\lambda\left(t \mid X_{i}\right)=\lambda_{0}(t) \exp \left(X_{i} \beta\right)
$$


where $\lambda_{0}(t)$ is the baseline hazard function at time $t$ and $\beta$ is a vector of unknown parameters. For the general case of $n$ failure times and multiple $X$ variables, estimation of $\beta$ is based on the partial likelihood

$$
P L(\beta)=\prod_{i=1}^{n}\left(\frac{\exp \left(X_{i} \beta\right)}{\sum_{l \in R_{i}} \exp \left(X_{l}^{T} \beta\right)}\right)^{\omega_{i}}
$$

where $R_{i}$ is the set of individuals at risk at time $t_{i}$ and $\omega_{i}$ an indicator whether or not individual $i$ is censored.

One potential problem in estimating (2) arises from the feedback of spell duration to the covariates. For example, a covariate may depend on whether or not a spell has ended or is still ongoing. It is possible to estimate (2) consistently if we assume that the hazard at time $t$ conditional on the covariates at time $t$ depends only on the lagged realizations of those covariates (Wooldridge, 2002). While this may be a reasonable assumption in the case of slow-moving variables - so that a change in spell status does not affect that variable in the same year, but only with a lag - it may not always be the case. Importantly, to address this issue we take a different approach: in order to avoid making any assumptions about ruling out contemporaneous feedback from the end of a growth spell to the time-varying covariates within the current time period, we lag all right-hand-side variables by one year.

\section{B. BMA for survival models}

Suppose that there are many potential covariates and there is uncertainty about the possible models. Cox proportional hazards modeling can be carried out within BMA following Volinksy et al. (1997). ${ }^{12}$ The general BMA principles in that context are discussed in detail in Raftery et al. (1997) and Hoeting et al. (1997), so we only provide some basic intuition behind the approach.

Let $\theta$ be a quantity of interest and $D$ denote the data. Suppose that the parameter space can be divided into $K$ regions (models). Then Bayesian inference about $\theta$ is constructed using $\mathrm{BMA}$, based on the posterior distribution

\footnotetext{
${ }^{12}$ Volinsky et al. (1997) apply their Bayesian Model Averaging for survival models methodology in a Cardiovascular Health Study assessing the risk of a stroke. Their code for Bayesian Model Averaging for Cox proportional hazards models for censored survival data "bic.surv" is available at http://www.research.att.com/ volinsky/bma.html.
} 


$$
p(\theta \mid D)=\sum_{j=1}^{K} p\left(\theta \mid D, M_{j}\right) p\left(M_{j} \mid D\right),
$$

which follows by the law of total probability. Therefore, the full posterior distribution of $\theta$ is a weighted average of the posterior distributions under each model $\left(M_{1}, \ldots, M_{K}\right)$, where the weights are the posterior model probabilities $p\left(M_{j} \mid D\right)$. The posterior model probabilities are obtained using

$$
p\left(M_{j} \mid D\right)=\frac{p\left(D \mid M_{j}\right) p\left(M_{j}\right)}{\sum_{l=1}^{K} p\left(D \mid M_{l}\right) p\left(M_{l}\right)},
$$

where $p\left(M_{j}\right)$ is the prior model probability, and $p\left(D \mid M_{l}\right)$ is the integrated likelihood of model $M_{l}$ given by

$$
p\left(D \mid M_{j}\right)=\int p\left(D \mid \theta, M_{j}\right) p\left(\theta \mid M_{j}\right) d \theta .
$$

The likelihood in (6) and the term $p\left(\theta \mid D, M_{j}\right)$ in (4) require integration which is possible in closed form for the general linear model, but not the case for the Cox model. Raftery et al. (1996) and Volinsky et al. (1997) discuss several approximations that can be adopted to implement the procedure. We follow Volinsky (1997) for the implementation of BMA in this context, and further assume a uniform distribution over the model space, which implies that there is no preference for a specific model.

\section{Model Specification and Africa Interactions}

The last building block of our methodology is the model specification. As discussed earlier, that in addition to examining the robustness of growth spell determinants for the world sample, we are interested in identifying differences between Africa and the non-Africa sample. This effectively reduces to examining the impact of parameter heterogeneity by incorporating interaction terms similarly to Masanjala and Papageorgiou (2008). Starting from the specification in (2) we define the hazard rate to be estimated for a model $M_{j}$ as

$$
\lambda(t)=\lambda_{0}(t) \exp \left(X_{j}^{1} \beta^{1}+I \times X_{j}^{2} \beta^{2}\right),
$$

where $X^{1}$ is the matrix of regressors, $I$ is an indicator variable taking the value of one if the country is in Africa and zero otherwise and $X^{2} \subseteq X^{1}$. Therefore, the model space includes 18 regressors, their interaction with the Africa dummy variable, and the dummy variable 
itself, for a total of 37 variables for the interactions sample. For the world sample, only 18 regressors are used.

Inclusion probabilities can be constructed for every explanatory variable $Z_{k}$ as

$$
p\left(Z_{k} \mid D\right)=\sum_{j=1}^{K} I\left(Z_{k} \mid M_{j}\right) p\left(M_{j} \mid D\right)
$$

where $I\left(Z_{k} \mid M_{j}\right)=1$ if $Z_{k} \in M_{j}$, and 0 if $Z_{k} \notin M_{j}$. Using (4), posterior means and variances can be constructed for the parameters of interest for the world sample as

$$
E\left(\theta_{k} \mid D\right)=\sum_{j=1}^{K} E\left(\theta_{k} \mid D, M_{j}\right) p\left(M_{j} \mid D\right) .
$$

We are also interested in assessing the differential impact of $I \times x_{k}$ in (7) where $x_{k}$ is a covariate in $X^{2} \subseteq X^{1}$. Therefore, posterior inclusion probabilities for the Africa (non-Africa) samples are based on the interaction terms (non-interaction terms). For a covariate $x_{k}$ posterior means for the non-Africa sample are based on $\beta_{k}^{1}$, while for the Africa sample $\beta_{k}^{A f r i c a}=\beta_{k}^{1}+\beta_{k}^{2}$. For the composite term, we calculate posterior variances based on $\operatorname{var} \beta_{k}^{\text {Africa }}=\operatorname{var} \beta_{k}^{1}+\operatorname{var} \beta_{k}^{2}+2 \operatorname{cov}\left(\beta_{k}^{1}, \beta_{k}^{2}\right)$.

\section{Results}

\section{A. Impact of Model Uncertainty}

We begin by demonstrating how model uncertainty can influence inferences. In particular, we examine how fragile results of ad hoc specifications may be, by estimating "kitchen sink" regressions based on different models, effectively, a subset of the universe of possible models based on the explanatory variables. ${ }^{13}$ Since no explicit theory exists to guide the choice of determinants of growth spells, in effect, each of these specifications (models) can be equally likely (or equally important) in explaining the duration of growth spells. The goal of this "kitchen sink" exercise is not to draw conclusions from the alternative specifications, but merely to expose the issue of model uncertainty.

With this in mind, Table 3 presents exponentiated regression coefficients ("hazard ratios") for several ad hoc regressions using the full sample and various sub-samples of the potential

\footnotetext{
${ }^{13}$ For similar expositions of how fragile ad hoc regressions may be in the broader context of growth regressions see Tsangarides (2003) and Mirestean and Tsangarides (2009).
} 
determinants. ${ }^{14}$ The estimated hazard ratios in Table 3 represent the factor by which the hazard rate changes when the covariate increases by one unit. For example, a hazard ratio of 1.15 suggests that a unit increase in the regressor increases the risk that the spell will end in the next period by 15 percent. Hazard ratios of less than 1 have a "protective" effect as they help to sustain the spell, while hazard ratios equal to 1 have no effect on spell duration.

Looking at the estimates in Table 3, it is striking to see how inferences change - both in terms of statistical significance and estimated elasticities - with only small variations in the set of explanatory variables. The first specification uses the full set of variables (column (1)) and identifies initial income, total education, changes in the US interest rate, change in oil price, external debt liabilities, and government balance to GDP as statistically significant determinants of spell duration. Increases in initial income, US interest rate, external debt liabilities and government balance increase the risk of the growth spell ending in the next period, while the opposite is true for education and oil price changes. Next, simply restricting the set of explanatory variables to the "neoclassical" variables (column (2)), causes the statistical significance of initial income and education to disappear. Also, adding sequentially shocks and exogenous factors and political variables in columns (3) and (4) turns population growth and terms of trade statistically significant, and oil price change drops from the list. Removing the "neoclassical" variables from the list of regressors in column (5) again results in changes in the regressors' significance: the overvaluation index and droughts become significant, while oil price change, debt liabilities, and fiscal balance lose their significance.

Further, in columns (6) to (20) we add regressors sequentially, starting from the specification in column (2). Again, the statistical significance of the estimated parameters changes dramatically. Variables not statistically significant in column (1) - for example, terms of trade growth, capital flows, inflation, and autocracy - appear as statistically significant in at least some specifications, while statistically significant variables in column (1) lose their significance in several specifications. Perhaps more worrisome are cases such as in columns (1) and (8) where statistically significant coefficients of oil price change alternate from statistically significant hazard ratios below one (positive effect on spell) to hazard ratios above one (negative effect on spell).

Overall, results in Table 3 confirm the common tendency for some empirical investigations to yield fragile econometric estimates, and suggest that lessons drawn from ad hoc specifications can be problematic. These findings also underscore the importance of incorporating model uncertainty in the estimation, which is the purpose of this paper.

\footnotetext{
${ }^{14}$ All specifications are estimated using Cox proportional-hazards regression model with STATA's stcox command with robust standard errors.
} 


\section{B. Robustness Analysis Using BMA}

We now turn to the main focus of our paper and apply the BMA methodology to investigate the determinants of growth spells. Table 4 presents results from our baseline estimation based on a universe of all possible models for three sample groups, Africa, non-Africa and the world. Recall that the set of variables for the Africa and non-Africa samples includes 37 variables, namely the 18 regressors, the 18 interactions with the sub-Saharan Africa dummy variable and the sub-Saharan Africa dummy variable itself). The world sample is estimated using the 18 variables.

Our priors are based on the assumption that each variable considered has the same probability of being included in the model, that is, equal to 0.50 . Table 4 presents results in separate panels, from the Africa, non-Africa (rest of the world), and world (global sample as a whole). The posterior inclusion probabilities shown in the first column of each panel in Table 4 reflect how much the data favors including a particular variable in the regression. So, variables for which the posterior inclusion probability is above the prior of 0.50 are considered robust, and highlighted in the Tables. Posterior inclusion probabilities non-Africa and Africa samples are calculated based on the non-interaction and the interaction variables, respectively. The unconditional means and standard deviations (shown in the third and fourth columns, respectively), are computed taking into account all the possible models. ${ }^{15}$ Hazard ratios (the exponentiated coefficients) and their standard deviations are shown in the next two columns.

Estimates in Table 4 suggest that several factors influence growth spells in one of the two samples only. Starting with the non-Africa sample, posterior inclusion probabilities suggest that four variables - initial income, terms of trade growth, inflation, and exchange rate undervaluation - affect growth spell duration in the non-Africa sample but do not have an effect in Africa. In particular, a percentage increase in exchange rate overvaluation or inflation increases the probability that the growth spell will end in the non-Africa sample by 2.7 and 1.9 percent, respectively, while a one percent improvement in terms of trade has a protective effect on the growth spell, that is, increases the probability it will continue by 1.4 percent. ${ }^{16}$ All three variables are ineffective in the Africa sample, with inclusion probabilities of less than 10 percent. Higher initial income is also associated with higher probability that the spell will end in the non-Africa sample. To the extent that growth spells or growth downbreaks are part of the (conditional) convergence process, this finding suggests that as countries get closer to the frontier they start growth spells at higher initial

\footnotetext{
${ }^{15}$ The conditional standard deviation does provide one measure of how well a particular variable is estimated, but the ratio of the mean to the standard deviation cannot, strictly speaking, be interpreted as a $t$-statistic since the posterior density is not a sampling distribution.

${ }^{16}$ The inflation measure is $100 \log (1+\pi)$, where $\pi$ is the $\log$ difference of the price level. At low inflation rates, $100 \log (1+\pi)$ is approximately linear, so that one percentage point increase in $100 \log (1+\pi)$ inflation is about the same as a one point rise in the rate of inflation.
} 
incomes, and these spells are more likely to end suddenly. Our results on inflation and exchange rate overvaluation are consistent with the findings of BOZ who also conclude that overvalued exchange rates which undermine growth in the manufacturing sector and nominal instability proxied by inflation are negatively related to spell duration. The effect of positive terms of trade shocks are also consistent with Rodrik (1999) and BOZ.

Further, two variables affect Africa distinctly and are completely ineffective in the nonAfrica sample. Increases in openness are associated with lower spell duration, while climate conditions - proxied by the cumulative number of droughts - have a very large negative effect on spell duration. The finding on openness is in line with Rodriguez and Rodrik (2000) who challenge the conclusion of a number of studies that openness is associated with higher growth rates. In addition trade liberalization dummies (e.g. Wacziarg and Welch, 2003), aim to capture a change in openness, our measure of openness - based on the ratio of the sum of exports and imports to GDP-is intended to capture the level of openness. ${ }^{17}$ It may also be consistent with the literature investigating how the impact of trade openness on the growth rate of per capita income varies with the conditional distribution of growth.

Finally, three variables are equally effective in predicting growth spells in both the Africa and non-Africa samples. Increases in human and physical capital proxied by total years of education, the investment to GDP ratio, and exogenous shocks help sustain the growth spells in both Africa and the rest of the world. However, the marginal effects of these variables differ substantially across the two samples. First, the protective effect of investment on the growth spell is almost twice in Africa compared to the non-Africa sample ( 9 and 5.4 percent, respectively), while an additional year of education increases the probability a growth spell will be sustained by 87 percent in Africa and 37 percent in the non-Africa sample. In addition, changes in the U.S. interest rate are much more detrimental to growth spells in the non-Africa sample compared to the Africa one: a one percentage point (100 basis points) increase in U.S. rate is estimated to reduce the duration of the spell length by 19.5 percent in the non-Africa sample but only by 11.1 percent in Africa.

Overall, results in Table 4 from the Africa, non-Africa, and world samples suggest that determinants of growth spells in Africa are different from those in the rest of the world. At the same time, differences in the identified robust determinants in each of the two groups do not suggest that these determinants are not important in determining growth spells in their respective samples. Rather, that these determinants have a less important role than the ones identified as robust.

\footnotetext{
${ }^{17}$ To test the robustness of this finding we are experimenting with constructing an alternative measure used in BOZ (which follows Pritchett (1996)) to adjust for cross-country differences in size, access to the sea, and distance to export markets, and whether or not the country is an energy producer. An alternative measure is to use the Wacziarg-Welch index of liberalization.
} 
The identified robust determinants seem consistent with several conclusions in the literature on broader economic growth. These include the importance and value of physical and human capital (proxied by investment and years of education) in the context of the Solow (1957) and augmented Solow model (Mankiw, Romer, and Weil, 1992), which seem to be particularly important in sustaining spells in Africa. The results are also consistent with the negative effect of shocks (proxied by changes in the U.S. rate, terms of trade, droughts) on spell duration (Rodrik, 1999; and Easterly et al., 1993). Finally, we also find evidence that macroeconomic instability (proxied by inflation and exchange rate overvaluation) are negatively associated with the length of growth spells (Fischer, 1993) particularly in the non-Africa sample.

\section{Conclusion}

We examine what determines growth spells in Africa and in the rest of the world using BMA techniques for proportional hazards models. We relate the probability that growth spells end to the various determinants including exogenous shocks, human capital, macroeconomic and sociopolitical and factors and investigate whether these robust determinants operate differently in Africa than in the rest of the world.

We find that determinants of growth spells in Africa are indeed different from those in the rest of the world. In particular, initial income, terms of trade, exchange rate undervaluation, inflation, openness and droughts have a distinct impact in only one of the two samples. The impact of openness and droughts is unique to the Africa sample, while terms of trade, exchange rate undervaluation, and inflation appear to influence only the non-Africa sample. Three variables (investment, total years of education and U.S. interest rate changes) affect both groups but the marginal impact is substantially different between the two groups.

Our findings suggest that properly accounting for model uncertainty is important for policymakers seeking to use findings of growth analyses to offer policy advice. Policy analysis and recommendations should not be based on one specification - which, as we have shown, results in fragile conclusions about the relevance of a particular determinant - but rather should reflect model uncertainty. In addition, in the context of Africa vis-à-vis the rest of the world, our findings suggest that what is good for sustaining growth spells around the world is not necessarily good for sustaining spells in Africa. We identify a handful of economic characteristics that influence growth spells in Africa, physical and human capital accumulation, openness, and droughts. Further work needs to be done to examine how these characteristics operate, how they are differentiated, and how they interact. But the paper's findings already raise several questions in the context of sustaining growth in Africa: what is the relative importance of physical and human capital accumulation, how (or how fast) African economies should open up to the rest of the world, and how to limit the adverse impact of droughts through setting up crop insurance systems or putting greater policy focus on sectors other than agriculture. 


\section{References}

Acemoglu, D., S. Johnson and J. A. Robinson, 2001, "The Colonial Origins of Comparative Development: An Empirical Investigation," American Economic Review, Vol. 91, pp. 1369-1401.

Aizenman J. and M. Spiegel, 2007, “Takeoffs,” NBER Working Paper No. 13084 (Cambridge: National Bureau of Economic Research).

Antoshin, S., A. Berg and M. Souto, 2008, "Testing for Structural Breaks in Small Samples," Working Paper No. 75 (Washington: International Monetary Fund).

Artadi, E.V. and X. Sala-i-Martin, 2003, "The Economic Tragedy of the XXth Century: Growth in Africa," NBER Working Paper No. 9865 (Cambridge: National Bureau of Economic Research).

Bai, J. and P. Perron, 1998, "Estimating and Testing Linear Models with Multiple Structural Changes," Econometrica, Vol. 66, No 1 (January), pp. 47-78.

, 2003, "Computation and Analysis of Multiple Structural Change Models," Journal of Applied Econometrics, Vol. 18, pp. 1-22.

Berg, A. and J. Ostry, 2011, "Inequality and Unsustainable Growth: Two Sides of the Same Coin?” Staff Discussion Note No. 11/108 (Washington: International Monetary Fund).

Berg, A., J. Ostry and J. Zettelmeyer, 2012, "What Makes Growth Sustained," Journal of Development Economics, forthcoming.

Block, S.A., 2001, “Does Africa Grow Differently?” Journal of Development Economics Vol. 65, pp. 443-467.

Brock,W. and S. Durlauf, 2001, "Growth Economics and Reality," World Bank Economic Review, Vol.15, pp. 229-272.

Burnside, C. and D. Dollar, 2000, "Aid, Policies, and Growth," American Economic Review, Vol. 90, pp. 847-868.

Chen, H., A. Mirestean and C. Tsangarides, 2009, "Limited Information Bayesian Model Averaging for Dynamic Panels with Short Time Periods," IMF Working Paper 09/74.

Collier, P. and J. W. Gunning, 1999, “Explaining African Economic Performance,” Journal of Economic Literature, Vol. 37, pp. 64-111.

Cox, D. R., 1972, "Regression Models and Life Tables (with Discussion)," Journal of the Royal Statistical Society, Vol. 34, pp. 187-220. 
Durlauf, S., P. Johnson and J. Temple, 2005, "Growth Econometrics," in P. Aghion and S. Durlauf (eds.), Handbook of Economic Growth Vol. IA (Elsevier: North Holland).

Durlauf, S.N., A. Kourtellos, and C.M. Tan, 2008, “Are Any Growth Theories Robust?” Economic Journal, Vol. 118, No. 527, pp. 329-46.

Easterly, W., M. Kremer, L. Pritchett, and L. Summers, 1993, "Good Policy or Good Luck? Country Growth Performance and Temporary Shocks," Journal of Monetary Economics, Vol. 32, pp. 459-483.

Easterly, W. and R. Levine, 1997, “Africa’s Growth Tragedy: Policies and Ethnic Divisions,” Quarterly Journal of Economics, Vol. 112, pp. 1203-1250.

Fernández, C., E. Ley and M. Steel, 2001, "Model Uncertainty in Cross-Country Growth Regressions," Journal of Applied Econometrics, Vol. 16, pp. 563-576.

Fischer, S. (1993) "The Role of Macroeconomic Factors in Growth," Journal of Monetary Economics, Vol. 32, pp. 485-512.

Frankel, J. A. and D. Romer, 1999, “Does Trade Cause Growth?” American Economic Review, Vol. 89, pp. 379-99.

Hausmann, R., L. Prichett and D. Rodrik, 2005, “Growth Accelerations," Journal of Economic Growth, Vol. 10, pp. 303-329.

Hausmann, R., J. Hwang and D. Rodrik, 2007, "What you Export Matters," Journal of Economic Growth, Vol. 12, pp. 1-25.

Hausmann, R., F. Rodriguez and R. Wagner, 2006, "Growth Collapses," Working Paper No. 136 (Cambridge, Massachusetts: Center for International Development).

Hausmann, R. and B. Klinger, 2007, "The Structure of the Product Space and the Evolution of Comparative Advantage," CID Working Paper No. 146 (Cambridge, Massachusetts: Center for International Development, Harvard University).

Jerzmanowski, M., 2006, "Empirics of Hills, Plateaus, Mountains and Plains: A MarkovSwitching Approach to Growth," Journal of Development Economics, Vol. 81, pp. $357-385$.

Jones, B. F. and B. A., Olken, 2008, “The Anatomy of Start-Stop Growth,” Review of Economics and Statistics, Vol. 90, pp. 582-587.

Knack, S., and P. Keefer, 1995, "Institutions and Economic Performance: Cross-country Tests Using Alternative Institutional Measures," Economics and Politics, Vol. 7, pp. $207-227$.

Lancaster, T., 1985, “Generalized Residuals and Heterogeneous Duration Models with Application to the Weibull Model," Journal of Econometrics, Vol. 28, pp. 155-169. 
Leamer, E., 1978, Specification Searches: ad hoc Inference with Non-Experimental Data, New York: Wiley.

Levine, R., 1997, "Financial Development and Economic Growth: Views and Agenda," Journal of Economic Literature, Vol. XXXV, pp. 688-726.

Mankiw, G., D. Romer, and D. Weil, 1992, “A Contribution to the Empirics of Economic Growth," Quarterly Journal of Economics, Vol. 107, pp. 407-37.

Masanjala W. and C. Papageorgiou, 2008, "Rough and Lonely Road to Prosperity: a Reexamination of the Sources of Growth in Africa Using Bayesian Model Averaging," Journal of Applied Econometrics, Vol. 23, pp. 671-682.

Mirestean, A. and C. Tsangarides, 2009, "Growth Determinants Revisited," IMF Working Paper No. 268 (Washington: International Monetary Fund).

Pattillo, C., S. Gupta, and K. Carey, 2005, "Sustaining Growth Accelerations and Pro-Poor Growth in Africa," IMF Working Paper No. 195 (Washington: International Monetary Fund).

Pritchett, L., 2000, "Understanding Patterns of Economic Growth: Searching for Hills among Plateaus, Mountains, and Plains," World Bank Economic Review, pp. 221-250.

Raftery, A.E., 1995, “Bayesian Model Selection in Social Research,” Sociological Methodology, Vol. 25, pp. 111-163.

Raftery, A., D. Madigan and C. Volinsky, 1996, "Accounting for Model Uncertainty in Survival Analysis Improves Predictive Performance (with discussion)," in Bayesian Statistics 5 (J. Bernardo, J. Berger, A. Dawid and A. Smith, eds.) pp. 323-349 (Oxford University Press).

Rodriguez, F. and D. Rodrik, 2000, “Trade Policy and Economic Growth: A Skeptic's Guide to the Cross-National Evidence," NBER Macroeconomics Annual, Vol. 15, pp. 261325 (Chicago: The University of Chicago Press).

Rodrik, D., 1998, “Trade Policy and Economic Performance in Sub-Saharan Africa," NBER Working Paper No. 6562 (Cambridge: National Bureau of Economic Research).

Sachs, J.D. and A.M. Warner, 1995, "Natural Resource Abundance and Economic Growth," NBER Working Paper 5398 (Cambridge: National Bureau of Economic Research).

Rodrik, D., 1999, "Where Did All the Growth Go? External Shocks, Social Conflict, and Growth Collapses," Journal of Economic Growth, Vol. 4, pp. 385-412. ,2008, "The Real Exchange and Economic Growth,” Brookings Papers on Economic Activity. 
Sala-i-Martin, X., G. Doppelhofer and R. Miller, 2004, "Determinants of Long-Term Growth: A Bayesian Averaging of Classical Estimates (BACE) Approach," American Economic Review, Vol. 94, pp. 813-835.

Temple, J., 1999, “The New growth Evidence,” Journal of Economic Literature, Vol. 37, pp.112-156.

Tsangarides, C., 2004, “A Bayesian Approach to Model Uncertainty," IMF Working Paper No.04/68 (Washington: International Monetary Fund).

Tsangarides, C., 2005, “Growth Empirics under Model Uncertainty: Is Africa Different?" IMF Working Paper No.05/18 (Washington: International Monetary Fund).

Volinsky, C., D. Madigan, A. Raftery and R. Kronmal, 1997, "Bayesian Model Averaging in Proportional Hazard Models: Assessing the Risk of a Stroke," Journal of the Royal Statistical Society, pp. 433-448.

Wacziarg, R. and K. Welch, 2003, “Trade Liberalization and Growth: New Evidence," NBER Working Paper No. 10152 (Cambridge: National Bureau of Economic Research).

Woolridge, J., 2002, Econometric Analysis of Cross Section and Panel Data, Cambridge: MIT Press. 


\section{Table 1. Growth Breaks by Country Group}

\begin{tabular}{|c|c|c|c|c|c|c|c|c|c|}
\hline \multirow[b]{2}{*}{ Country group } & \multirow[b]{2}{*}{$\begin{array}{c}\text { No. of } \\
\text { countries }\end{array}$} & \multicolumn{2}{|c|}{$\begin{array}{c}\text { Minimum length: } \\
5 \text { years }\end{array}$} & \multicolumn{2}{|c|}{$\begin{array}{c}\text { Minimum length: } \\
8 \text { years }\end{array}$} & \multicolumn{2}{|c|}{$\begin{array}{c}\text { Minimum length: } \\
5 \text { years }\end{array}$} & \multicolumn{2}{|c|}{$\begin{array}{c}\text { Minimum length: } \\
8 \text { years }\end{array}$} \\
\hline & & Total & $\begin{array}{l}\text { Average } \\
\text { break } \\
\text { size } \%\end{array}$ & Total & $\begin{array}{c}\text { Average } \\
\text { break } \\
\text { size } \%\end{array}$ & Total & $\begin{array}{c}\text { Average } \\
\text { break } \\
\text { size } \%\end{array}$ & Total & $\begin{array}{c}\text { Average } \\
\text { break } \\
\text { size } \%\end{array}$ \\
\hline & \multicolumn{5}{|c|}{ Upbreaks $p=0.10$} & \multicolumn{4}{|c|}{ Upbreaks $p=0.25$} \\
\hline High Income ${ }^{1}$ & 37 & 25 & 7.0 & 11 & 5.0 & 49 & 4.9 & 20 & 4.4 \\
\hline Emerging Asia & 22 & 27 & 5.5 & 19 & 5.6 & 40 & 5.2 & 28 & 4.7 \\
\hline Latin America & 29 & 33 & 6.1 & 20 & 6.0 & 46 & 5.8 & 28 & 5.5 \\
\hline Africa & 43 & 40 & 11.8 & 22 & 10.3 & 73 & 9.8 & 38 & 8.8 \\
\hline Other ${ }^{2}$ & 9 & 12 & 8.2 & 6 & 6.7 & 13 & 8.1 & 8 & 6.1 \\
\hline \multirow[t]{2}{*}{ Total upbreaks } & 140 & 137 & 7.9 & 78 & 6.9 & 221 & 6.8 & 122 & 6.0 \\
\hline & \multicolumn{5}{|c|}{ Downbreaks $p=0.10$} & \multicolumn{4}{|c|}{ Downbreaks $p=0.25$} \\
\hline High Income & 37 & 38 & -6.0 & 21 & -5.3 & 63 & -5.1 & 33 & -4.3 \\
\hline Emerging Asia & 22 & 20 & -7.4 & 15 & -6.0 & 36 & -6.0 & 22 & -5.2 \\
\hline Latin America & 29 & 35 & -6.1 & 24 & -5.5 & 52 & -5.7 & 30 & -5.8 \\
\hline Africa & 43 & 44 & -9.0 & 26 & -8.0 & 70 & -8.6 & 35 & -7.7 \\
\hline Other ${ }^{2}$ & 9 & 13 & -9.6 & 10 & -7.2 & 13 & -10.3 & 11 & -7.6 \\
\hline Total downbreaks & 140 & 150 & -7.2 & 96 & -6.3 & 234 & -6.7 & 131 & -6.0 \\
\hline
\end{tabular}

${ }^{1}$ Includes Japan, Korea, Singapore, Hong Kong SAR and Taiwan Province of China.

${ }^{2}$ Includes Middle East, North Africa and Caribbean countries. 


\section{Table 2. Stylized Facts about Growth Spells ${ }^{1}$}

\begin{tabular}{|c|c|c|c|c|c|c|c|c|c|c|}
\hline \multirow[b]{3}{*}{ Country group } & \multicolumn{5}{|c|}{ Frequency and duration of growth spells } & \multicolumn{5}{|c|}{ Average growth before, during and after spells } \\
\hline & \multirow{2}{*}{$\begin{array}{c}\text { No. of } \\
\text { countries }\end{array}$} & \multirow{2}{*}{$\begin{array}{l}\text { No. of } \\
\text { spells }\end{array}$} & \multirow{2}{*}{$\begin{array}{c}\text { Mean } \\
\text { duration }\end{array}$} & \multicolumn{2}{|c|}{$\begin{array}{c}\% \text { of spells lasting } \\
\text { at least }\end{array}$} & \multicolumn{3}{|c|}{ Average growth } & \multicolumn{2}{|c|}{3 years ... } \\
\hline & & & & 10 years & 16 years & before & during & after & $\begin{array}{l}\text { before } \\
\text { start }\end{array}$ & $\begin{array}{l}\text { after } \\
\text { end }\end{array}$ \\
\hline & \multicolumn{10}{|c|}{ Complete spells } \\
\hline High Income ${ }^{2}$ & 37 & 9 & 12.7 & 66.7 & 11.1 & 0.6 & 7.9 & -0.6 & 0.2 & -1 \\
\hline Emerging Asia & 22 & 6 & 21.3 & 83.3 & 66.7 & -1.5 & 7.0 & -1.3 & -1.3 & -1.6 \\
\hline Latin America & 29 & 18 & 8.4 & 16.7 & 11.1 & 0.3 & 5.1 & -0.9 & -0.4 & -0.8 \\
\hline Africa & 43 & 11 & 5.7 & 0.0 & 0.0 & -0.9 & 9.5 & -3.2 & -3.1 & -3.7 \\
\hline \multirow[t]{2}{*}{ Other ${ }^{3}$} & 9 & 5 & 12.2 & 40.0 & 20.0 & -4.2 & 6.3 & -2.5 & -2.4 & -3.4 \\
\hline & \multicolumn{10}{|c|}{ Incomplete spells } \\
\hline High Income ${ }^{2}$ & 37 & 11 & 25.5 & 90.9 & 72.7 & -0.7 & 5.9 & & -1.6 & \\
\hline Emerging Asia & 22 & 14 & 20.4 & 71.4 & 50.0 & -0.6 & 4.9 & & -0.8 & \\
\hline Latin America & 29 & 7 & 21.1 & 100.0 & 71.4 & -4.2 & 5.1 & & -7.3 & \\
\hline Africa & 43 & 19 & 14.2 & 68.4 & 21.1 & -5.1 & 7.5 & & -7.8 & \\
\hline Other $^{3}$ & 9 & 4 & 20.3 & 50.0 & 50.0 & 0.0 & 5.3 & & -1.1 & \\
\hline
\end{tabular}

${ }^{1}$ Minimum length of spell 5 years; $p=0.10$.

${ }^{2}$ Includes Japan, Korea, Singapore, Hong Kong SAR and Taiwan Province of China.

${ }^{3}$ Includes Middle East, North Africa and Caribbean countries. 
Table 3. Evidence for Lack of Robustness from Ad hoc "Kitchen Sink" Regressions of Spell Duration"

\begin{tabular}{|c|c|c|c|c|c|c|c|c|c|c|c|c|c|c|c|c|c|c|c|c|}
\hline Variables & (1) & $(2)$ & (3) & (4) & (5) & (6) & (7) & (8) & (9) & (10) & (11) & (12) & (13) & (14) & (15) & (16) & (17) & (18) & (19) & (20) \\
\hline \multirow[t]{2}{*}{ Initial income per capita } & $1.209^{*}$ & 1.041 & $1.135^{\star \star \star}$ & $1.124^{\star \star}$ & & 1.048 & 1.049 & 1.040 & 1.057 & $1.076^{*}$ & 1.020 & 1.037 & 1.043 & 1.040 & 1.029 & 1.063 & 1.029 & 1.043 & 1.046 & 1.041 \\
\hline & $(0.119)$ & $(0.0446)$ & $(0.0522)$ & $(0.0518)$ & & $(0.0484)$ & $(0.0452)$ & $(0.0411)$ & $(0.0513)$ & $(0.0442)$ & $(0.0498)$ & $(0.0431)$ & $(0.0444)$ & $(0.0447)$ & $(0.0428)$ & $(0.0612)$ & $(0.0527)$ & $(0.0462)$ & $(0.0481)$ & $(0.0446)$ \\
\hline \multirow[t]{2}{*}{ Population growth } & 1.285 & 0.997 & $1.202^{*}$ & $1.335^{\star \star}$ & & 1.159 & 1.135 & 0.986 & 0.958 & $1.227^{\star \star}$ & 1.098 & 0.974 & 0.990 & 0.998 & 0.953 & 0.896 & $1.256^{*}$ & 1.046 & 1.125 & 0.997 \\
\hline & $(0.351)$ & $(0.164)$ & $(0.115)$ & $(0.155)$ & & $(0.122)$ & $(0.110)$ & $(0.159)$ & $(0.154)$ & $(0.120)$ & $(0.143)$ & $(0.153)$ & $(0.164)$ & $(0.166)$ & $(0.173)$ & $(0.160)$ & $(0.152)$ & $(0.176)$ & $(0.113)$ & $(0.164)$ \\
\hline \multirow[t]{2}{*}{ Investment to GDP } & 0.983 & 1.006 & 1.015 & 1.018 & & 1.015 & 1.012 & 1.006 & 1.001 & 1.012 & 1.010 & 1.001 & 1.005 & 1.009 & 1.004 & 1.002 & 1.015 & 1.005 & 1.010 & 1.006 \\
\hline & $(0.0312)$ & $(0.0176)$ & $(0.0143)$ & $(0.0134)$ & & $(0.0121)$ & $(0.0147)$ & $(0.0165)$ & $(0.0184)$ & $(0.0123)$ & $(0.0160)$ & $(0.0185)$ & $(0.0174)$ & $(0.0160)$ & $(0.0110)$ & $(0.0164)$ & $(0.0108)$ & $(0.0169)$ & $(0.0110)$ & $(0.0176)$ \\
\hline \multirow[t]{2}{*}{ Total education years } & $0.535^{\star \star *}$ & 0.871 & $0.832^{*}$ & $0.809^{* *}$ & & 0.876 & 0.862 & 0.881 & 0.886 & 0.866 & 0.884 & 0.860 & 0.870 & 0.880 & $0.836^{*}$ & 0.891 & $0.846^{*}$ & 0.867 & $0.851^{*}$ & 0.871 \\
\hline & $(0.0908)$ & $(0.0801)$ & $(0.0780)$ & $(0.0830)$ & & $(0.0822)$ & $(0.0802)$ & $(0.0805)$ & $(0.0831)$ & $(0.0858)$ & $(0.0900)$ & $(0.0823)$ & $(0.0818)$ & $(0.0819)$ & $(0.0801)$ & $(0.0906)$ & $(0.0842)$ & $(0.0863)$ & $(0.0780)$ & $(0.0801)$ \\
\hline \multirow[t]{2}{*}{ Terms of trade growth } & 0.987 & & $0.982^{*}$ & 0.983 & 0.990 & $0.980^{\star \star}$ & & & & & & & & & & & & & & \\
\hline & $(0.0139)$ & & $(0.0103)$ & $(0.0105)$ & $(0.00991)$ & $(0.00865)$ & & & & & & & & & & & & & & \\
\hline US interest rate change & $(0.154)$ & & $(0.115)$ & $(0.125)$ & $(0.136)$ & & $(0.115)$ & & & & & & & & & & & & & \\
\hline \multirow{2}{*}{ Change in oil price } & $0.342^{\star \star \star}$ & & 0.956 & 0.912 & 0.814 & & & $1.455^{*}$ & & & & & & & & & & & & \\
\hline & $(0.135)$ & & $(0.251)$ & $(0.271)$ & $(0.200)$ & & & $(0.325)$ & & & & & & & & & & & & \\
\hline \multirow[t]{2}{*}{ Capital flows to GDP } & 0.112 & & & & 0.657 & & & & $4.716^{\star \star \star}$ & & & & & & & & & & & \\
\hline & $(0.523)$ & & & & $(2.750)$ & & & & $(1.953)$ & & & & & & & & & & & \\
\hline \multirow{2}{*}{ Drought } & 1.809 & & 1.754 & 1.887 & $2.124^{\star *}$ & & & & & 1.471 & & & & & & & & & & \\
\hline & $(1.096)$ & & $(0.697)$ & $(0.783)$ & $(0.813)$ & & & & & $(0.619)$ & & & & & & & & & & \\
\hline \multirow[t]{2}{*}{ External debt liabilities to GDP } & $1.009^{\star \star \star}$ & & & & $1.003^{*}$ & & & & & & 1.000 & & & & & & & & & \\
\hline & $(0.00227)$ & & & & $(0.00194)$ & & & & & & $(0.000570)$ & & & & & & & & & \\
\hline \multirow[t]{2}{*}{ Openness } & 1.000 & & & & 0.999 & & & & & & & 1.003 & & & & & & & & \\
\hline & $(0.00572)$ & & & & $(0.00299)$ & & & & & & & $(0.00216)$ & & & & & & & & \\
\hline \multirow[t]{2}{*}{ Log(1+inflation) } & 1.001 & & & & 1.003 & & & & & & & & & $1.007^{\star \star}$ & & & & & & \\
\hline & $(0.00694)$ & & & & $(0.00724)$ & & & & & & & & & $(0.00274)$ & & & & & & \\
\hline \multirow[t]{2}{*}{ Government balance to GDP } & $1.100^{* \star}$ & & & & 1.051 & & & & & & & & & & $1.071^{\star \star \star}$ & & & & & \\
\hline & $(0.0417)$ & & & & (0.0391) & & & & & & & & & & $(0.0178)$ & & & & & \\
\hline \multirow[t]{2}{*}{ Aid to GDP } & 0.950 & & & & 1.012 & & & & & & & & & & & 0.992 & & & & \\
\hline & $(0.0536)$ & & & & $(0.0274)$ & & & & & & & & & & & $(0.0294)$ & & & & \\
\hline \multirow[t]{2}{*}{ Difference in autocracy } & 1.104 & & & 1.092 & & & & & & & & & & & & & $1.180^{*}$ & & & \\
\hline & $(0.142)$ & & & $(0.0980)$ & & & & & & & & & & & & & $(0.113)$ & & & \\
\hline \multirow[t]{2}{*}{ Ethnic heterogeneity } & 0.994 & & & 0.999 & & & & & & & & & & & & & & 0.996 & & \\
\hline & $(0.00885)$ & & & $(0.00527)$ & & & & & & & & & & & & & & $(0.00533)$ & & \\
\hline \multirow[t]{2}{*}{ Shock to terms of trade growth } & 0.531 & & 0.665 & 0.665 & 0.975 & & & & & & & & & & & & & & 0.754 & \\
\hline & $(0.301)$ & & $(0.270)$ & $(0.274)$ & $(0.357)$ & & & & & & & & & & & & & & $(0.269)$ & \\
\hline Sub-Saharan Africa dummy & 0.520 & 0.894 & 0.958 & & 0.668 & & & & & & & & & & & & & & & 0.894 \\
\hline & $(0.392)$ & $(0.388)$ & $(0.408)$ & & $(0.386)$ & & & & & & & & & & & & & & & $(0.388)$ \\
\hline Observations & 563 & 966 & 845 & 757 & 680 & 898 & 901 & 966 & 884 & 932 & 829 & 966 & 966 & 954 & 929 & 719 & 864 & 889 & 876 & 966 \\
\hline Subjects & 50 & 73 & 67 & 62 & 66 & 69 & 68 & 73 & 71 & 70 & 68 & 73 & 73 & 73 & 71 & 62 & 65 & 70 & 68 & 73 \\
\hline Failures & 25 & 38 & 35 & 33 & 31 & 35 & 35 & 38 & 37 & 36 & 33 & 38 & 38 & 38 & 36 & 33 & 33 & 37 & 35 & 38 \\
\hline
\end{tabular}


Table 4. Posterior Coefficient Estimates for Growth Spells for Africa, Non-Africa and World ${ }^{1}$

\begin{tabular}{|c|c|c|c|c|c|c|c|c|c|c|c|c|c|c|c|}
\hline \multirow[b]{2}{*}{ Regressors } & \multicolumn{5}{|c|}{ Africa $^{2}$} & \multicolumn{5}{|c|}{ Non-Africa $^{3}$} & \multicolumn{5}{|c|}{ World $^{4}$} \\
\hline & $\begin{array}{c}\mathrm{P}(\text { incl) } \\
\text { Interaction }\end{array}$ & $\begin{array}{c}\text { Mean } \\
\text { Composite }\end{array}$ & $\begin{array}{l}\text { Stand. Dev } \\
\text { Composite }\end{array}$ & Hazard & $\begin{array}{l}\text { St.Dev } \\
\text { Hazard }\end{array}$ & $P$ (incl) & Mean & Stand. Dev & Hazard & $\begin{array}{l}\text { St.Dev } \\
\text { Hazard }\end{array}$ & $P($ incl) & Mean & Stand. Dev & Hazard & $\begin{array}{l}\text { St.Dev } \\
\text { Hazard }\end{array}$ \\
\hline Initial income per capita & 45.2 & 1.515 & 1.339 & 4.551 & 6.093 & 100.0 & 0.432 & 0.089 & 1.541 & 0.136 & 100.0 & 0.426 & 0.085 & 1.531 & 0.130 \\
\hline Population growth & 3.5 & 0.029 & 0.130 & 1.029 & 0.134 & 7.9 & 0.020 & 0.110 & 1.020 & 0.112 & 6.9 & 0.004 & 0.067 & 1.004 & 0.068 \\
\hline Investment to GDP & 59.3 & -0.094 & 0.078 & 0.910 & 0.071 & 83.2 & -0.054 & 0.038 & 0.947 & 0.036 & 69.7 & -0.036 & 0.032 & 0.965 & 0.031 \\
\hline Total education years & 69.7 & -2.051 & 1.310 & 0.129 & 0.169 & 100.0 & -0.478 & 0.181 & 0.620 & 0.112 & 100.0 & -0.581 & 0.154 & 0.560 & 0.086 \\
\hline Terms of trade growth & 0.4 & -0.014 & 0.017 & 0.987 & 0.017 & 57.5 & -0.014 & 0.017 & 0.986 & 0.017 & 37.4 & -0.009 & 0.015 & 0.991 & 0.015 \\
\hline US interest rate change & 64.4 & 0.105 & 0.171 & 1.111 & 0.190 & 66.3 & 0.178 & 0.184 & 1.195 & 0.220 & 26.7 & 0.047 & 0.101 & 1.048 & 0.105 \\
\hline Change in oil price & 3.6 & -0.260 & 0.778 & 0.771 & 0.600 & 25.1 & -0.304 & 0.599 & 0.738 & 0.442 & 30.9 & -0.259 & 0.494 & 0.771 & 0.381 \\
\hline Drought & 76.5 & 1.240 & 1.571 & 3.457 & 5.430 & 0.6 & 0.007 & 0.114 & 1.007 & 0.115 & 40.6 & 0.387 & 0.579 & 1.472 & 0.853 \\
\hline Shock to terms of trade growth & 1.8 & -0.047 & 0.349 & 0.954 & 0.333 & 1.7 & -0.012 & 0.112 & 0.988 & 0.111 & 25.1 & -0.148 & 0.345 & 0.863 & 0.298 \\
\hline Capital flows to GDP & 0.5 & -0.047 & 1.151 & 0.954 & 1.098 & 0.3 & -0.002 & 0.312 & 0.998 & 0.311 & 8.1 & -0.236 & 1.577 & 0.790 & 1.245 \\
\hline External debt liabilities to GDP & 2.5 & 0.001 & 0.004 & 1.001 & 0.004 & 31.1 & 0.001 & 0.002 & 1.001 & 0.002 & 74.6 & 0.004 & 0.003 & 1.004 & 0.003 \\
\hline Openness & 62.3 & 0.021 & 0.019 & 1.021 & 0.020 & 1.1 & 0.000 & 0.001 & 1.000 & 0.001 & 15.1 & -0.001 & 0.003 & 0.999 & 0.003 \\
\hline Overvaluation index & 0.7 & 0.027 & 0.010 & 1.028 & 0.010 & 99.9 & 0.027 & 0.009 & 1.027 & 0.009 & 99.9 & 0.023 & 0.007 & 1.023 & 0.007 \\
\hline Log(1+inflation) & 9.0 & 0.015 & 0.007 & 1.015 & 0.007 & 97.8 & 0.019 & 0.009 & 1.019 & 0.009 & 34.9 & 0.005 & 0.008 & 1.005 & 0.008 \\
\hline Government balance to GDP & 1.3 & 0.021 & 0.047 & 1.021 & 0.048 & 25.6 & 0.022 & 0.044 & 1.023 & 0.045 & 42.6 & 0.026 & 0.038 & 1.026 & 0.039 \\
\hline Aid to GDP & 2.0 & 0.005 & 0.027 & 1.005 & 0.027 & 10.9 & 0.006 & 0.023 & 1.006 & 0.023 & 23.8 & 0.011 & 0.026 & 1.011 & 0.027 \\
\hline Difference in autocracy & 2.1 & -0.001 & 0.098 & 0.999 & 0.098 & 0.2 & 0.000 & 0.013 & 1.000 & 0.013 & 6.6 & 0.007 & 0.066 & 1.007 & 0.066 \\
\hline Ethnic heterogeneity & 16.3 & 0.001 & 0.025 & 1.001 & 0.025 & 33.9 & -0.006 & 0.011 & 0.994 & 0.011 & 17.4 & -0.002 & 0.005 & 0.998 & 0.005 \\
\hline Sub-Saharan Africa dummy & & & & & & 11.3 & 0.186 & 0.780 & 1.205 & 0.940 & & & & & \\
\hline
\end{tabular}

${ }^{1}$ Minimum length of spell 5 years; $p=0.10$. Boxed posterior coefficient estimates represent variables that pass the threshold of 0.50 .

${ }^{2}$ Africa sample: composite posterior coefficient estimates are obtained from the specification with interactions.

${ }^{3}$ Non-Africa sample: posterior coefficient estimates are obtained from the specification with interactions.

${ }^{4}$ World sample: posterior coefficient estimates are obtained from the specification using all countries and no interactions. 
Figure 1a. Upbreaks and Downbreaks: Hills, Cliffs, Moutnails, and Plateaus
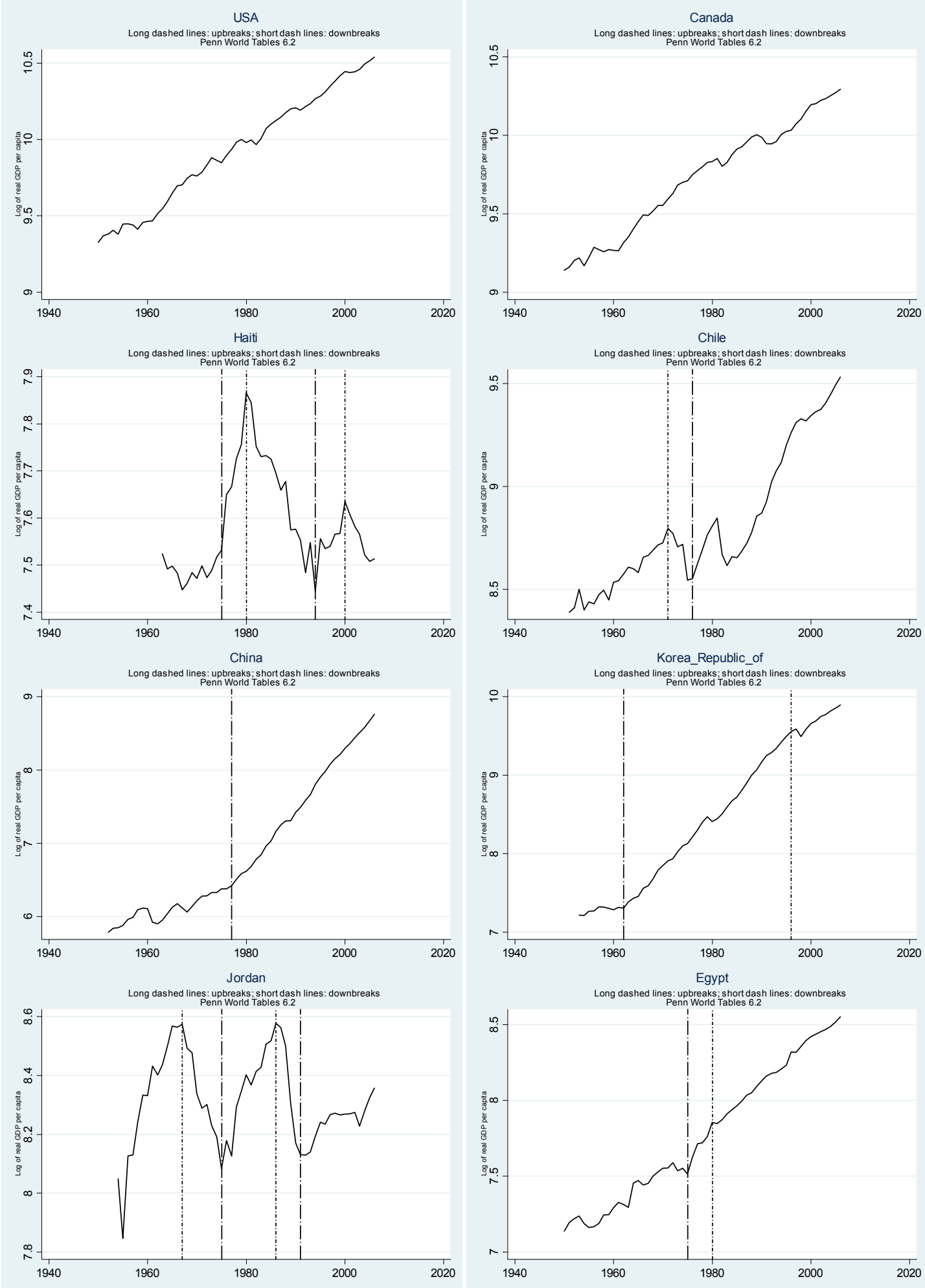

${ }^{1}$ Minimum length of spell 5 years; $p=0.10$. 
Figure 1b. Upbreaks and Downbreaks: Hills, Cliffs, Mountains, and Plateaus in Africa
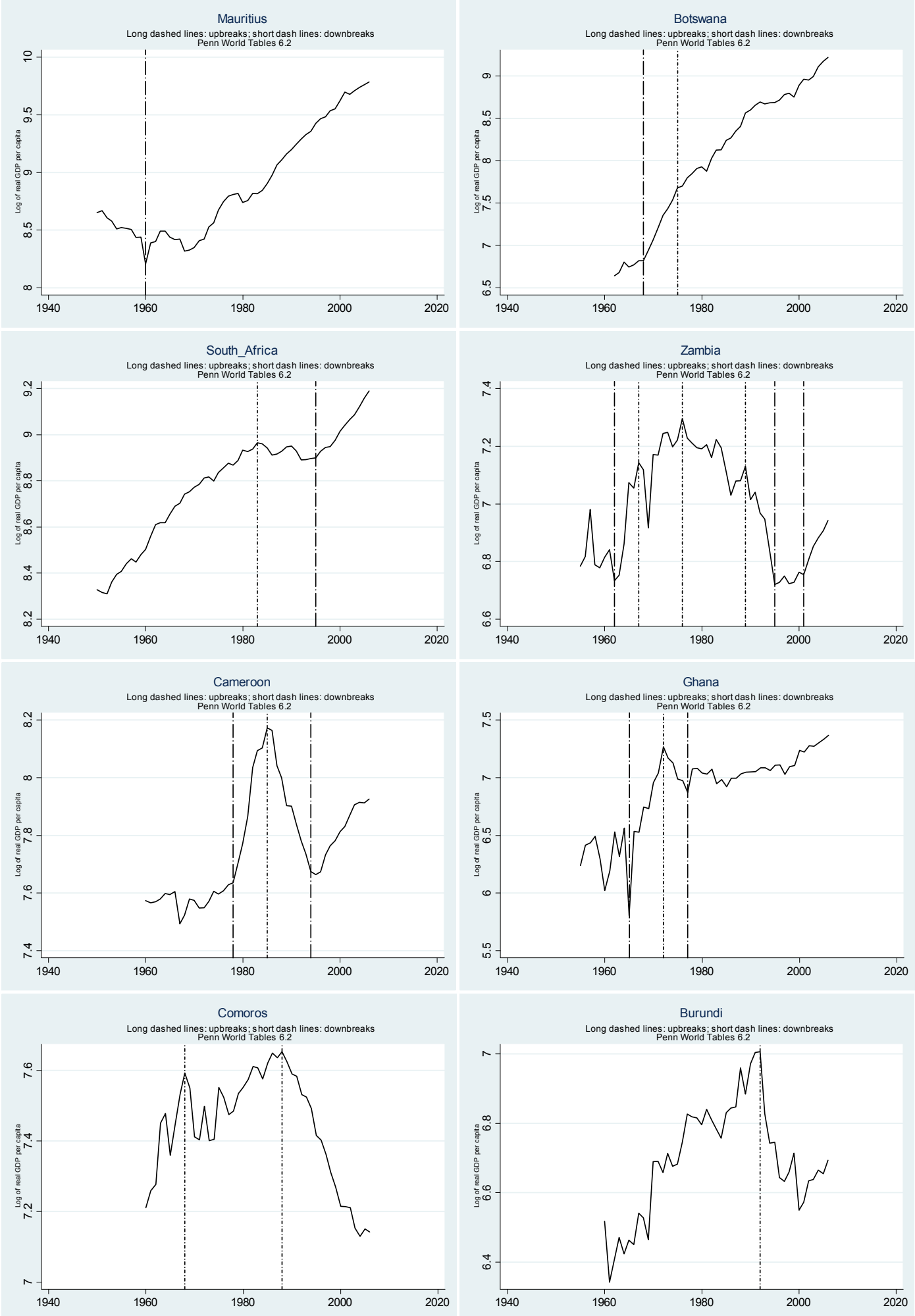

${ }^{1}$ Minimum length of spell 5 years; $p=0.10$. 
Figure 2a. Distribution of Upbreaks ${ }^{1}$

(By country group and period)

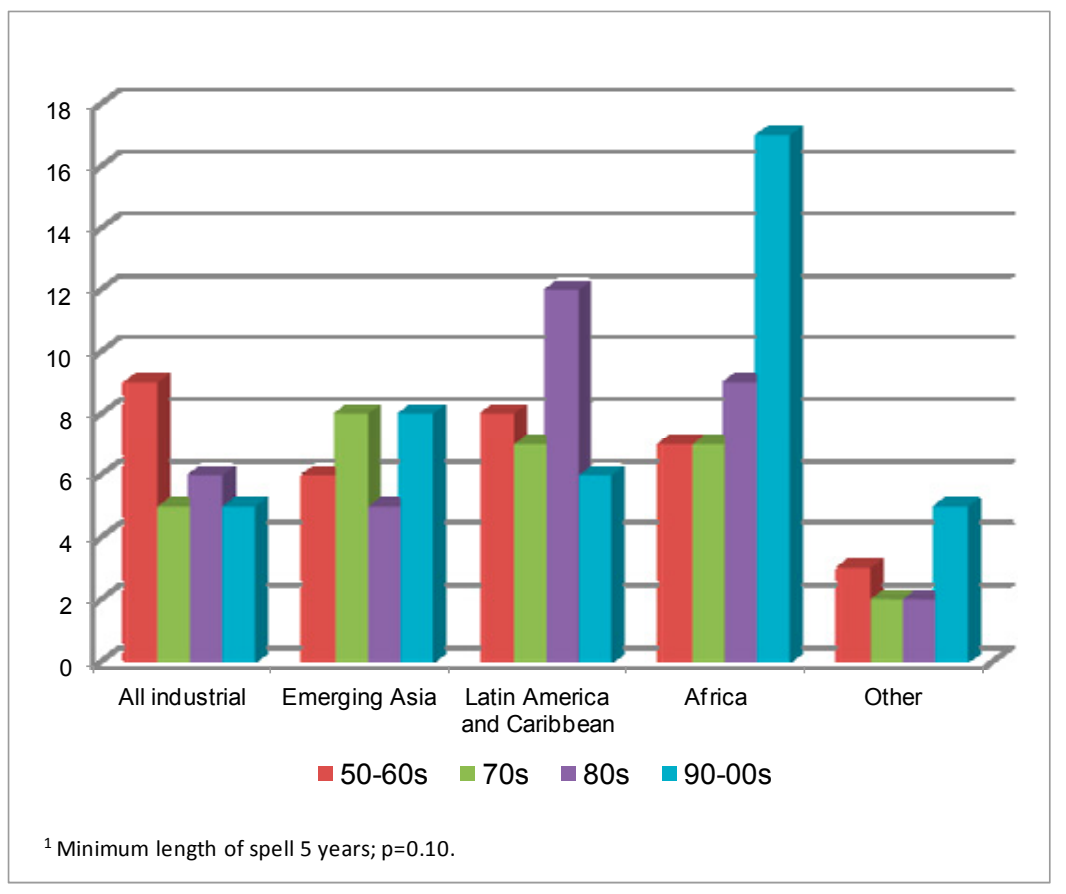

Figure 2b. Distribution of Downbreaks ${ }^{1}$

(By country group and period)

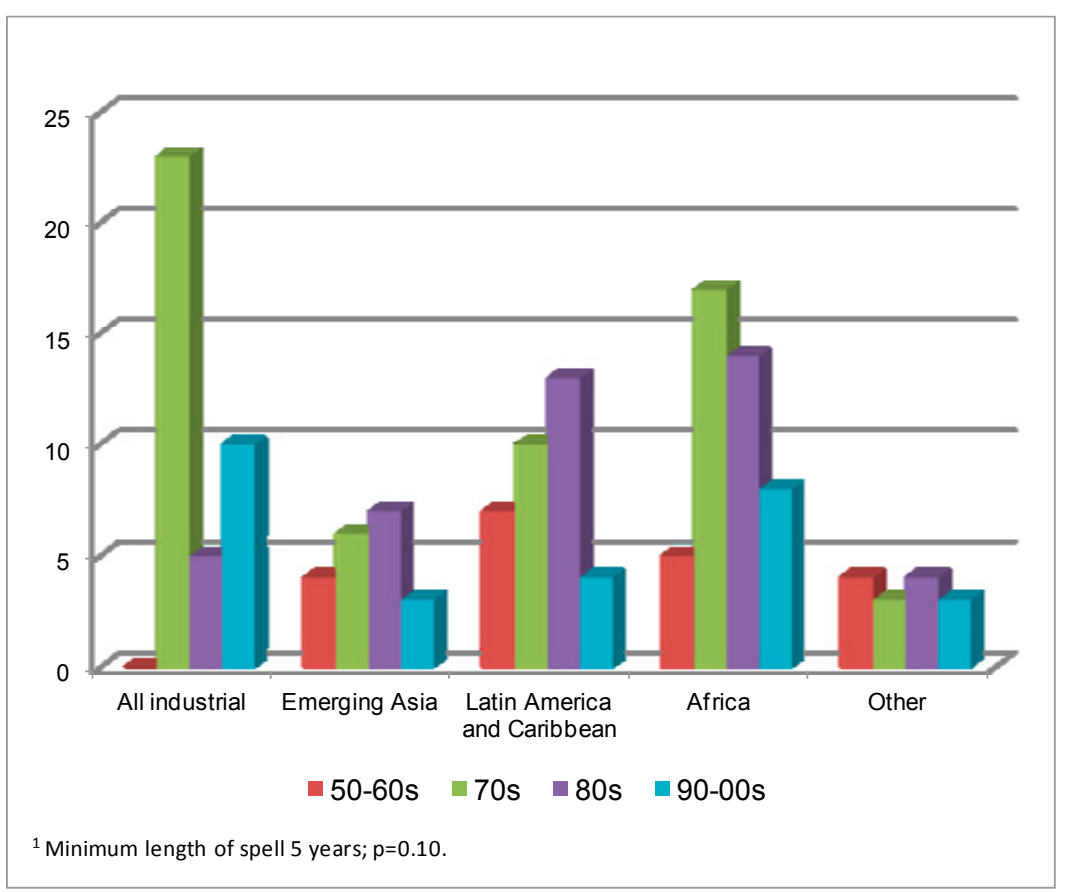


Figure 3. Duration of Growth Spells and Explanatory Variables

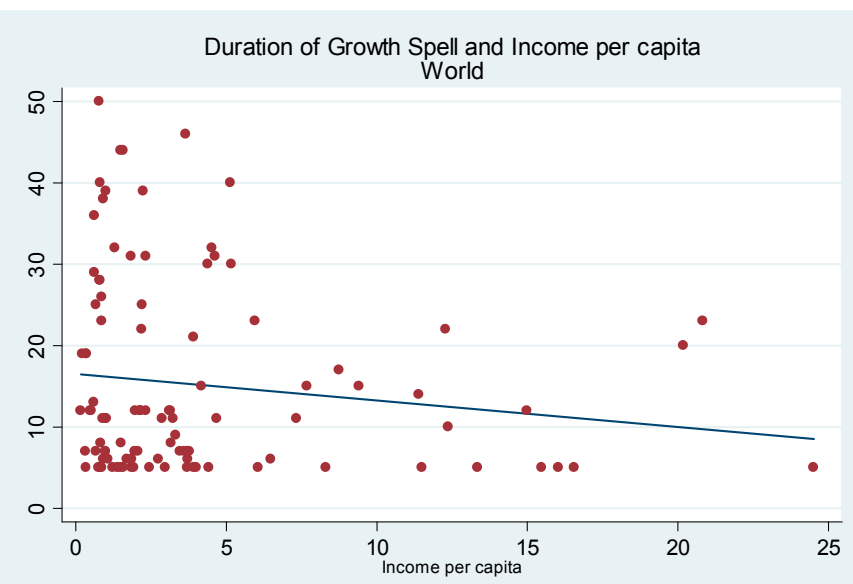

$h=5 ; p=10$
Source: Penn World Tables and author's calculation

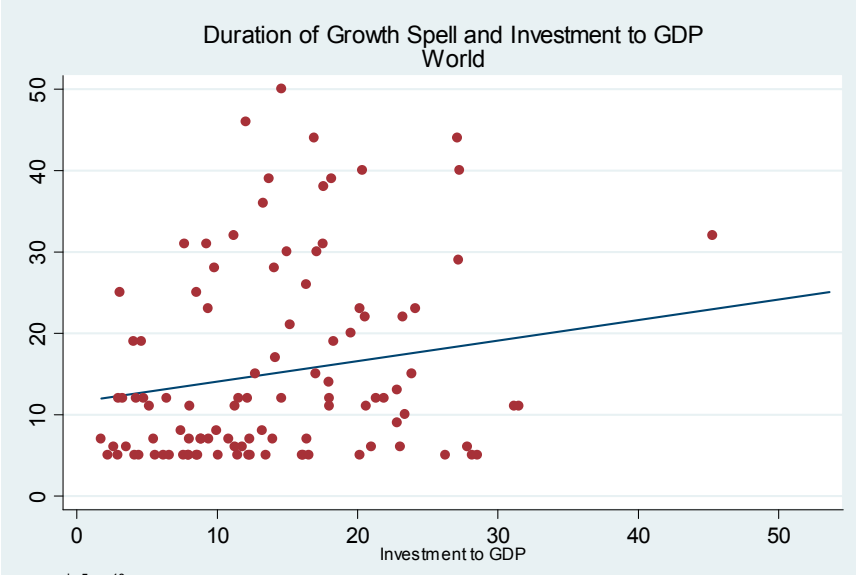

$h=5 ; p=10$
Source: Penn World Tables and author's calculation

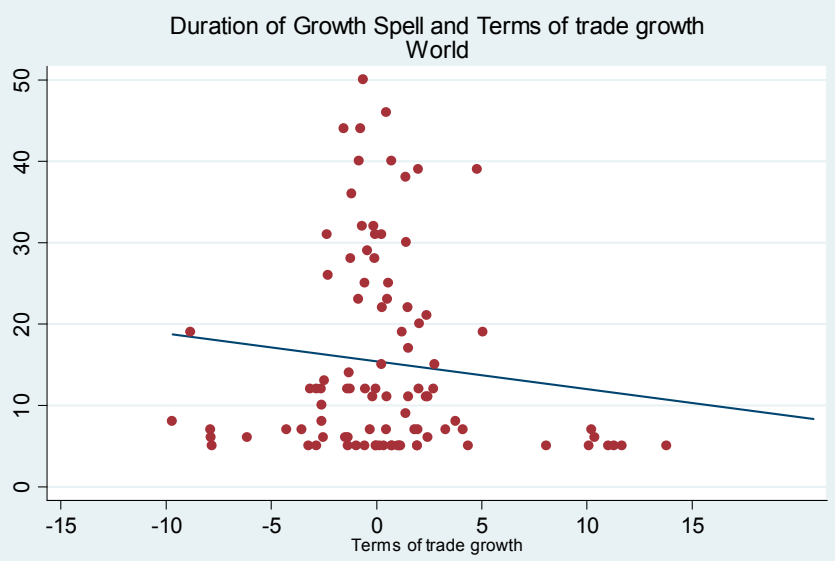

$h=5 ; p=10$
Source: Penn World Tables and author's calculation

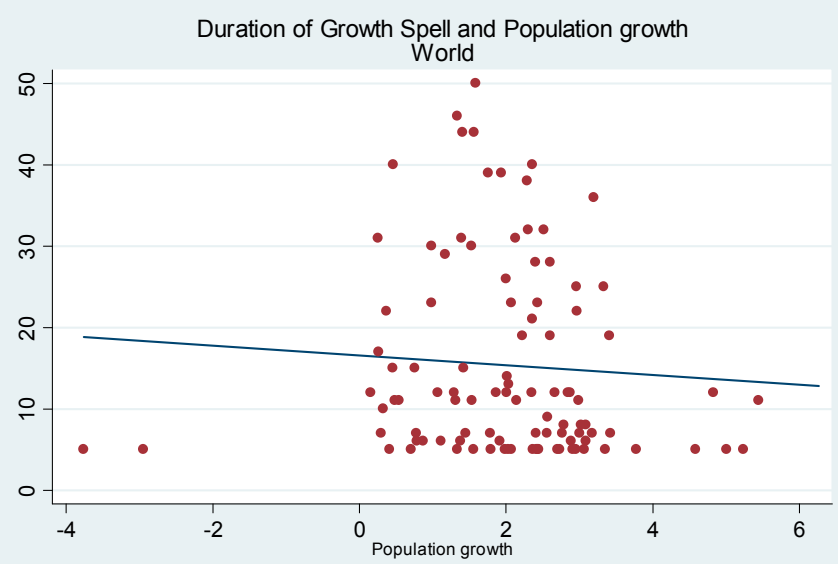

$h=5 ; p=10$
Source: Penn World Tables and author's calculation

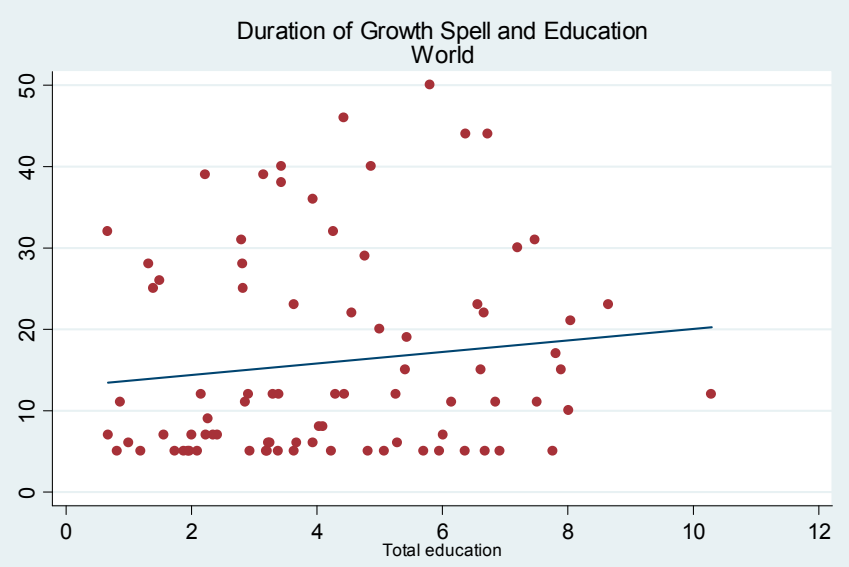

$h=5 ; p=10$
Source: Penn World Tables and author's calculation

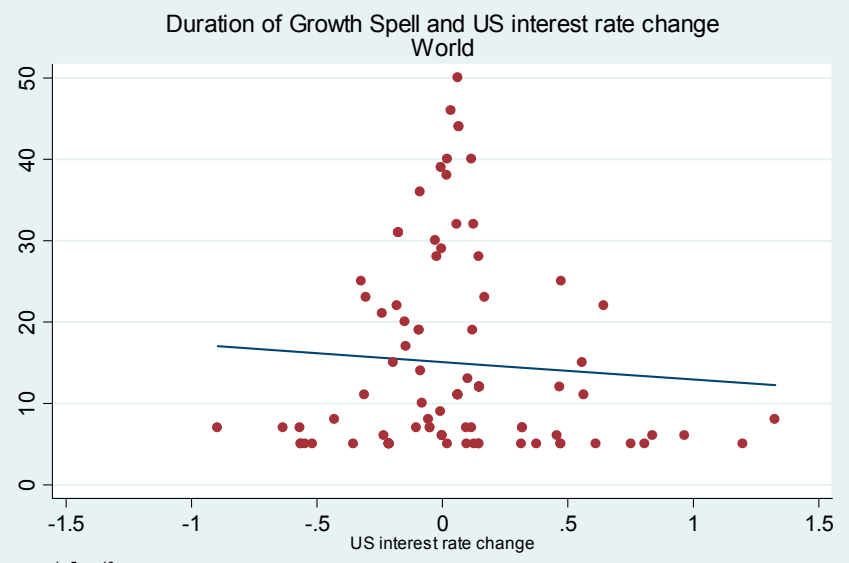

$h=5 ; p=10$
Source: Penn World Tables and author's calculation 
Figure 3 cont. Duration of Growth Spells and Explanatory Variables

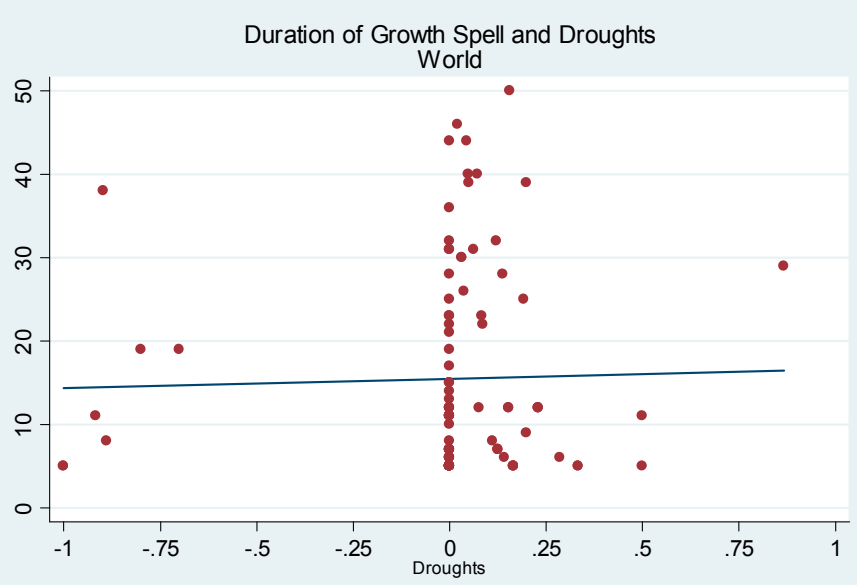

$\mathrm{h}=5 ; \mathrm{p}=10$
Source: Penn World Tables and author's calculation

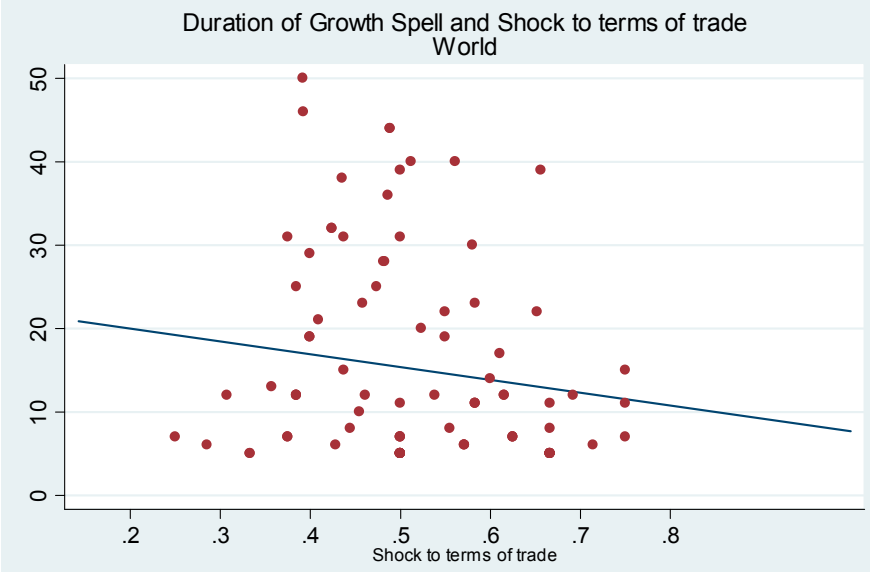

$h=5 ; p=10$
Source: Penn World Tables and author's calculation

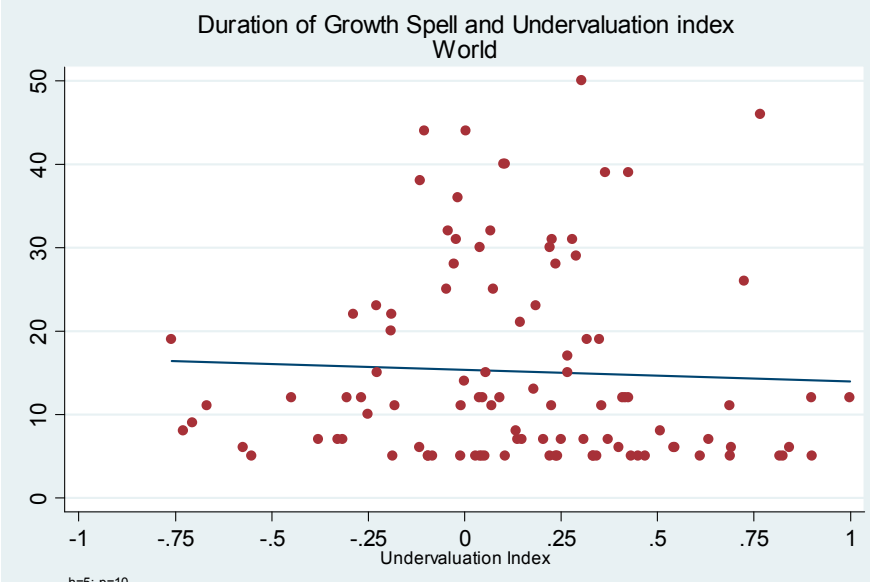

$h=5 ; p=10$
Source: Penn World Tables and author's calculation

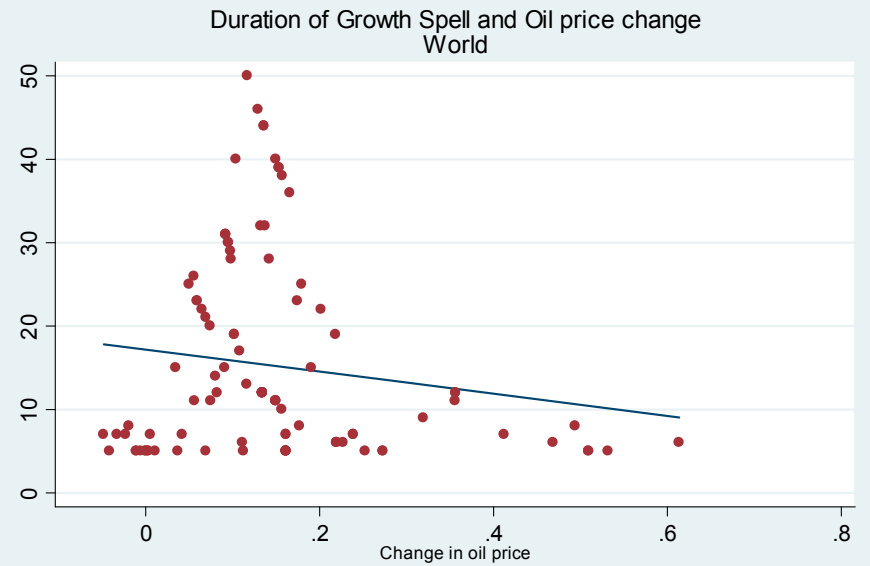

$h=5 ; p=10$
Source: Penn World Tables and author's calculation

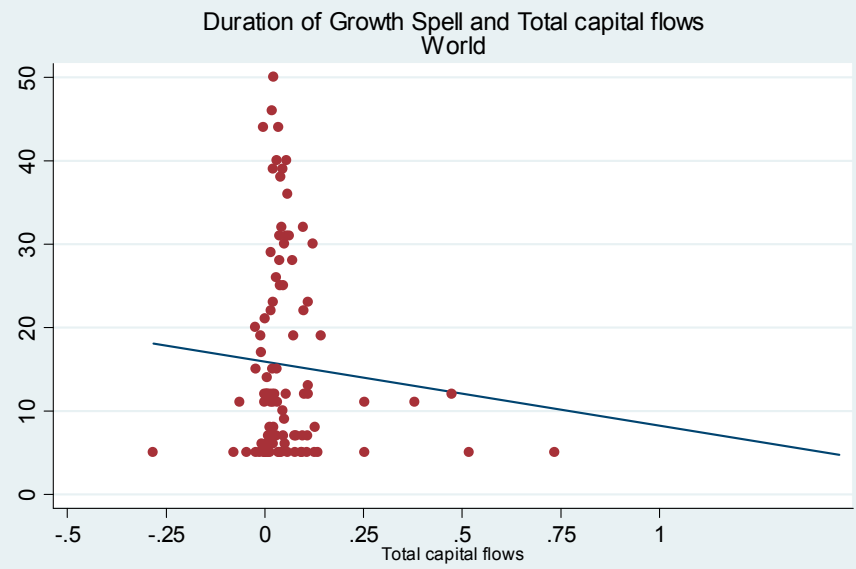

$h=5 ; p=10$
Source: Penn World Tables and author's calculation

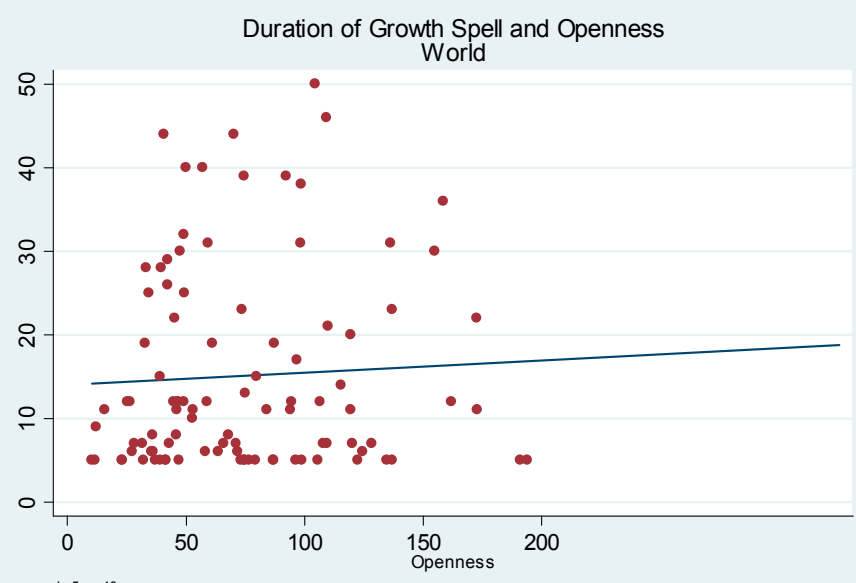

$h=5 ; p=10$
Source: Penn World Tables and author's calculation 
Figure 3 cont. Duration of Growth Spells and Explanatory Variables
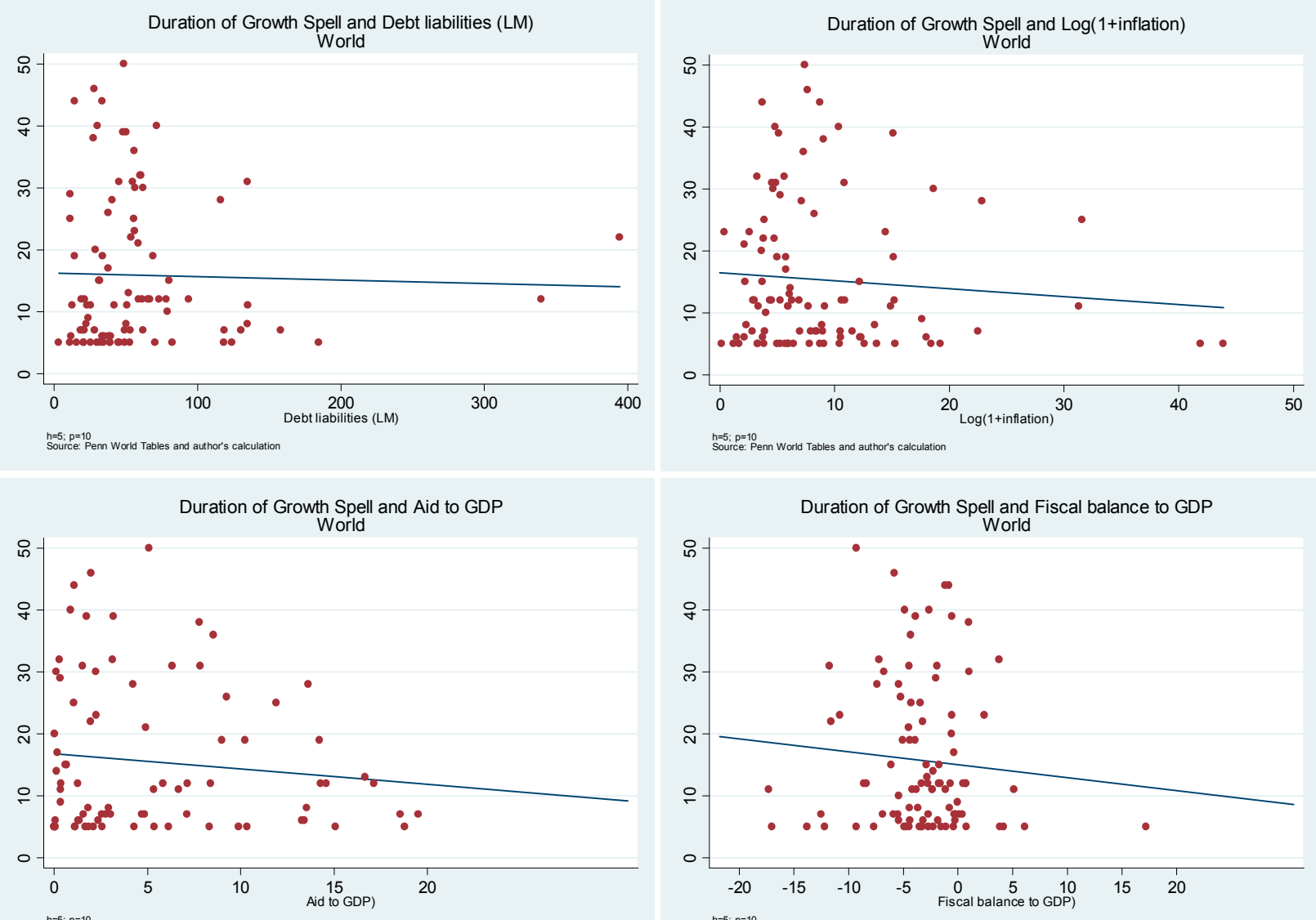

$\mathrm{h}=5 ; \mathrm{p}=10$
Source: Penn World Tables and author's calculation

$h=5 ;$ p $=10$
Source: Penn World Tables and author's calculation
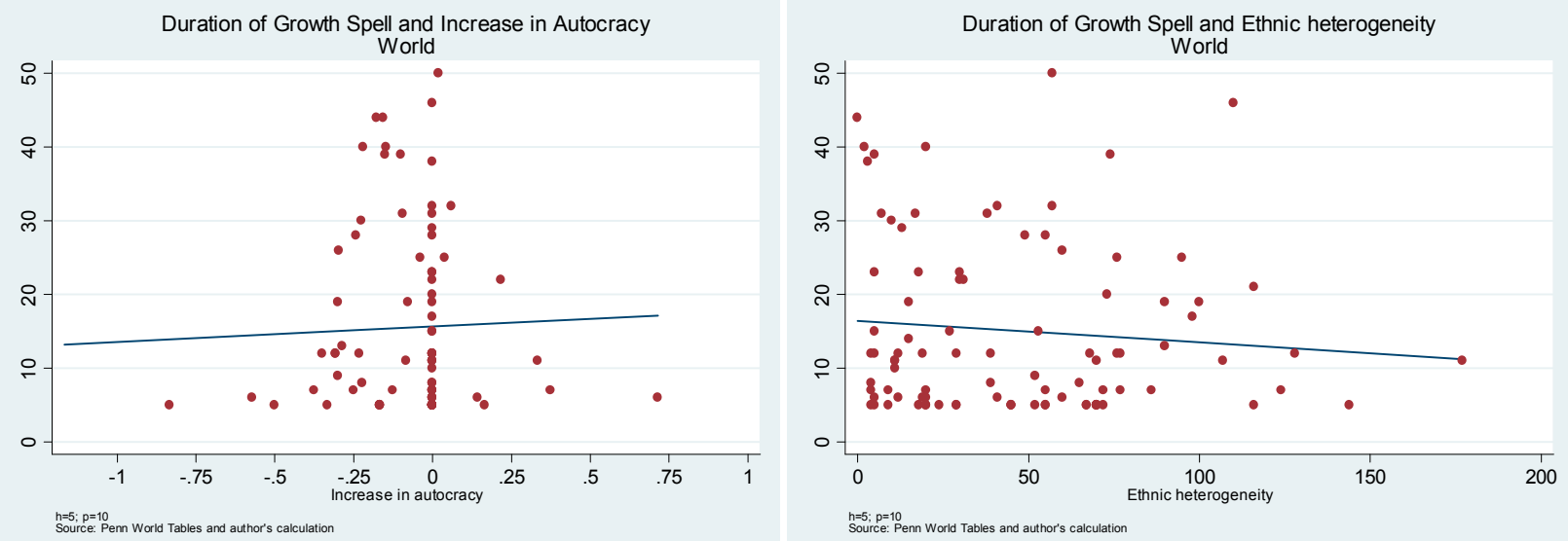


\section{Appendix \\ Data and Summary Statistics}

\section{Appendix Table 1: Variable Definitions and Sources}

\begin{tabular}{|c|c|c|}
\hline Description & Source & Details \\
\hline Initial income per capita & PWT 6.2 & Initial real GDP per capita (2000 US dollars at PPP) \\
\hline Population growth & PWT 6.2 & Annual population growth rate \\
\hline Investment to GDP & PWT 6.2 & Real investment as ratio to GDP (2000 US dollars at PPP) \\
\hline Total education years & Barro and Lee dataset & Total average stock of years of primary and secondary education \\
\hline Terms of trade growth & WEO & Ratio of export prices to import prices $(2000=100)$ \\
\hline US interest rate change & FED 3 month Treasury bill & Percent change \\
\hline Change in oil price & IFS & Growth rate of average petroleum crude price, in USD per barrel \\
\hline Drought & \multicolumn{2}{|c|}{ EM-DAT International Disaster Databası Cumulative number of drought disasters recorded by EM-DAT (1974-2004) } \\
\hline \multicolumn{2}{|c|}{ Shock to terms of trade growth WEO } & Shock to TOT growth if above 50th pctile for all countries each year \\
\hline Capital flows to GDP & WEO & Total net capital flows to GDP \\
\hline \multicolumn{2}{|c|}{ External debt liabilities to GDP Lane and Milesi-Ferretti, 2003} & External debt liabilities from IMF's (WEO) and World Bank's Global Development Finance database \\
\hline Openness & PWT 6.2 & Exports plus Imports divided by GDP, percent \\
\hline Undervaluation index & PWT 6.2 & Over/undervaluation index based on Rodrik (2008) \\
\hline $\log (1+$ inflation $)$ & IFS & Percent \\
\hline Government balance to GDP & WEO & Goverment fiscal balance in percent of GDP \\
\hline Aid to GDP & WDI & Aid in $\%$ of GDP \\
\hline Difference in autocracy & Polity IV & Change in the index (scale from 0 to 10 (most autocratic)) \\
\hline Ethnic heterogeneity & Sambanis 2001 (extended) & Ethnic heterogeneity (Vanhanen's measure): sum of racial, linguistic, and religious division rescaled 0-1 \\
\hline
\end{tabular}

